Advances in Cement Research Volume 30 Issue 1

Self-repairing properties of OPC clinker/natural zeolite blend in water and alkali carbonate environments at $270^{\circ} \mathrm{C}$ Pyatina, Sugama, Ronne and Trabits
Advances in Cement Research, 2018, 30(1), 8-23 http://dx.doi.org/10.1680/jadcr.16.00136 Paper 1600136

Received 28/09/2016; revised 21/06/2017; accepted 22/06/2017

Published online ahead of print 04/08/2017

Keywords: durability/pozzolans/well cements

Published with permission by the ICE under the CC-BY 4.0

license. (http://creativecommons.org/licenses/by/4.0/)
,

oe

$\overline{\text { Institution of Civil Engineers }}$

publishing

\title{
Self-repairing properties of OPC clinker/natural zeolite blend in water and alkali carbonate environments at $270^{\circ} \mathrm{C}$
}

Tatiana Pyatina

Sustainable Energy Technologies, Brookhaven National Laboratory, Upton, NY, USA (corresponding author: tpyatina@bnl.gov)

\section{Toshifumi Sugama}

Sustainable Energy Technologies, Brookhaven National Laboratory, Upton, NY, USA

\author{
Arthur Ronne \\ Stony Brook University, Stony Brook, NY, USA \\ George Trabits \\ Trabits Group, Wasilla, AK, USA
}

The $10 \mathrm{~d}$ recoveries of the mechanical properties and crack sealing of an ordinary Portland cement (OPC) clinker/natural zeolite (ferrierite (Fer)) blend modified or unmodified with silica were tested at $270^{\circ} \mathrm{C}$ in water and alkali carbonate environments. The recoveries of the samples depended on their modification with silica and the curing environment, but were more than $100 \%$ after repeated damage under some test conditions. The mechanical properties and phase compositions of recovered samples were evaluated by compressive strength measurements and $x$-ray diffraction, differential thermogravimetric analyses, Fourier transform infrared analyses and scanning electron microscopy coupled with energy dispersive $x$-ray spectroscopy. The sealing of $\mathbf{0 . 2 5} \mathbf{m m}$ wide and $\sim 2 \mathrm{~mm}$ deep cracks was visualised with a three-dimensional optical microscope. Fer decomposed under high-temperature alkaline conditions with the release of hydrolysates that, along with the hydrating clinker, participated in the formation of new phases contributing to strength recoveries. These phases included crystalline magnesium and aluminiumcontaining silicates, calcium and carbonated calcium silicates and amorphous hydrates. Crack sealing was complete for the silica-modified samples and partial for unmodified ones cured in carbonate environments. The sealing was very poor for samples cured in water. The main sealing phases included crystalline and amorphous silica, hightemperature-stable zeolites and talc mineral.

\section{Introduction}

For well cements, geothermal environments are among the most aggressive in terms of mechanical and chemical stresses, causing unavoidable concerns over short- and long-term cement sheath integrity. Cement failure can lead to the creation of micro-annuli or cracks, increased cement permeability and fluids migration, disbandment of cement from the casing and formations, casing corrosion by corrosive geo-fluids and collapse (Amin et al., 2009; McCulloch et al., 2003; Ravi et al., 2002; Teodoriu et al., 2013; Zhijun et al., 2013). Repairs to failed well cements are expensive and time consuming and are complicated by the difficulties of locating and accessing damaged areas.

The development of cost-effective self-repairing cement technologies that allow recovery of the original cement properties without human intervention is an economical way to obtain durable well integrity. Among the major technical strategies for developing self-healing cements, autogenous healing relies on the hydration of residual non-hydrated and partially hydrated cement particles by permeation of water through cracks and the carbonation of hydrates with crack plugging by the hydration and carbonation reaction products (Edvardsen, 1999; Huang et al., 2013; Talaiekhozan et al., 2014). Another, autogenous healing approach involves the incorporation of pozzolan-latent cementitious materials such as fly ash (Sahmaran et al., 2008, 2013; Termkhajornkit et al., 2009), ground granulated blast-furnace slag (GBFS) (Huang et al., 2014) and silica fume (Qian et al., 2010) as healing aids into cements. In contact with calcium- and sodium-containing alkaline fluids penetrating through the fractures, these nonreacted pozzolan materials form amorphous and crystalline calcium silicate, calcium aluminosilicate, sodium aluminosilicate and calcium(sodium) aluminosilicate products, which seal the cracks.

Aluminosilicate-based pozzolans can be natural, such as zeolites, metakaolin and clays, or industrial by-products including fly ashes and GBFS (Mertens et al., 2009). Among the natural pozzolans, zeolites are abundant worldwide. In the USA, the US Geological Survey estimated the reserves of zeolite minerals and zeolite-rich deposits to be 120 million and 10 trillion tonnes, respectively (Virta, 2015). As economical materials, zeolites have a high potential for substitution of cement, gypsum, bentonite, montmorillonite, peat, perlite and silica sand, and their application in cements have increased in the past decade.

As is well-documented (Ahmadi and Shekarchi, 2010; Bilim, 2011; Habert et al., 2008; Karadurt and Topcu, 2011; Mertens et al., 2009; Ortega et al., 2000; Perraki et al., 2010; Uzal et al., 2010; Yilmaz et al., 2007), the crystalline clinoptilolite zeolite can totally or partially substitute ordinary Portland cement (OPC) in blends with OPC or lime where calcium hydroxide initiates the pozzolanic reactions of clinoptilolite. 
Zeolites are crystalline hydrated aluminosilicate minerals and their structure is characterised by three-dimensional (3D) oxygen-linked $\left[\mathrm{SiO}_{4}\right]^{4-}$ and $\left[\mathrm{AlO}_{4}\right]^{5-}$ tetrahedral frameworks containing ion-exchangeable cations $\left(\mathrm{Na}^{+}, \mathrm{K}^{+}\right.$and $\left.\mathrm{Ca}^{2+}\right)$ and water molecules situated in their micropores and channels (Armbruster and Gunter, 1991; Curkovic et al., 1997). Substantial amounts of iron may be intercalated in the crystalline lattice of zeolite (Dubkov et al., 2002; Kiwi-Minsker et al., 2003; Perez-Ramirez et al., 2003). Under alkali attack of calcium hydroxide from the hydration of lime and OPC, the aluminosilicate framework of zeolites disintegrates to form calcium silicates, calcium aluminates and/or calcium aluminium silicates in reaction with calcium cations (Liguori et al., 2015; Özen et al., 2016; Perraki et al., 2005; Uzal and Turanli, 2012).

Compared with the properties of OPC-based cement, such pozzolan cements display improved resistance to sulfateinduced erosion and minimised water permeability; in addition, the formation of calcium-silicate-related swelling hydrogel is eliminated, thereby mitigating undesirable expansion-induced failure of concrete. On the other hand, they are slow to develop early strength and require increased water at mixing (Vejmelkova et al., 2015). To mitigate these drawbacks, different treatment techniques involving ultrafine pulverisation (Alexander, 1960; Day and Shi, 1994), thermal, hydrothermal and acid treatments (Collepardi et al., 1976; Costa and Massazza, 1977; Hemings et al., 1989; Seraj et al., 2016) and chemical methods (Shi and Day, 1993) have been employed over more than three decades. These treatments enhance the pozzolanic reactivity of zeolites through de-alumination, resulting in a loss of crystallinity. Correspondingly, the silicon/aluminium ratio of untreated clinoptilolite significantly increases after treatment (Ates and Hardacre, 2012; Cakicioglu-Ozkan and Ulku, 2005; Elaiopoulos et al., 2010; Misaelides et al., 1996; Zhang et al., 2002). Furthermore, under alkali conditions and elevated temperatures, zeolites undergo eventual decomposition of their crystalline structure as a result of silicon leaching (Bonilla et al., 2009).

Among the various zeolites, ferrierite (Fer) is especially attractive for high-temperature hydrothermal applications in geothermal cements because of the high stability of its structure against hydrothermal and chemical treatments (Bonilla et al., 2009; Wloch et al., 2006) necessary for successful autogenous healing, relying on latent pozzolanic reactions.

The work reported here evaluated the performance of an OPC clinker/Fer blend under the high-temperature hydrothermal conditions relevant for geothermal wells. Based on the reported performance of zeolite-modified cements, self-healing behaviour may be expected from the blend at high temperatures where zeolite may become reactive under the alkaline conditions of cement slurries. The purpose of the work was to establish the strength recoveries and fracture sealing of the clinker modified with Fer and to understand the underlying mechanisms of the material's healing.

\section{Experimental procedure}

A blend of OPC clinker (type I/II)/Fer/gypsum (65/30/5 wt $\%$ respectively) was prepared by intergrinding (without grinding aids) unground clinker and the natural zeolite to a final composite with a mean particle size of $24 \mu \mathrm{m}$ (the zeolite component, being softer, was ground to finer particles than the clinker in the final blend). The blend was provided by Trabits Group. OPC type I/II modified with silica powder $(30 \%$ by weight of cement) was used as a reference material in the strength recovery tests. The addition of crystalline silica to cement is commonly carried out for subterranean cementing at temperatures above about $90^{\circ} \mathrm{C}$ to avoid strength retrogression.

Carbon microfibres (7-9 $\mu \mathrm{m}$ in diameter and 100-200 $\mu \mathrm{m}$ long) were added to ensure controlled crack formation. The fibres, supplied by Asbury Carbon, had a density of 1.73$1.79 \mathrm{~g} / \mathrm{cm}^{3}$, carbon content of more than $94 \%$, tensile strength of 2.0-3.8 GPa and Young's modulus of 180-240 GPa. Silica powder (average particle size $\sim 15 \mu \mathrm{m}$ ) was added to half of the Fer-modified samples. The compositions of the tested blends are listed in Table 1.

The slurries were hand mixed at a water-to-blend mass ratio of $0 \cdot 54$, poured into $20 \times 40 \mathrm{~mm}$ cylindrical polyacrylic moulds and left to set for $24 \mathrm{~h}$ at room temperature and then under $99 \pm 1 \%$ humidity at $85^{\circ} \mathrm{C}$ for a further $24 \mathrm{~h}$, imitating wellplacement temperatures. The set samples were further cured for $24 \mathrm{~h}$ at $270^{\circ} \mathrm{C}$ in autoclaves filled with water or sodium carbonate solution, representing early curing under the static temperature of a hot geothermal well. The volumetric proportion of cement-to-solution was 1:3.5 and the pressure in the autoclave was $8 \cdot 27 \mathrm{MPa}$.

A solution of sodium carbonate at $0.05 \mathrm{M}$ was used to simulate the conditions of alkali carbonation in geothermal wells.

After curing, samples were crushed at their stress-strain yield point used to calculate the compressive strength and Young's modulus of the control and then autoclaved for a further $5 \mathrm{~d}$ at $270^{\circ} \mathrm{C}$ in carbonate or water environments to heal the damage. The crush tests and the $5 \mathrm{~d}$ autoclave-healing process were repeated, followed by final compressive strength measurements. Additionally, crack filling was examined on pre-cracked

Table 1. Tested formulations

\begin{tabular}{lccc} 
& OPC/silica & Clinker/Fer & Clinker/Fer/silica \\
\hline Clinker/Fer & - & $94 \cdot 3$ & 66 \\
OPC & 66 & - & - \\
Silica & $28 \cdot 3$ & - & $28 \cdot 3$ \\
Carbon & $5 \cdot 7$ & $5 \cdot 7$ & $5 \cdot 7$ \\
$\quad$ microfibres & & &
\end{tabular}


samples with cracks of $0.25 \mathrm{~mm}$ width and $\sim 2 \mathrm{~mm}$ depth made by inserting Teflon tabs into the slurries before their curing for $24 \mathrm{~h}$ at $270^{\circ} \mathrm{C}$ as described above. After the initial curing, the Teflon tabs were removed and crack sealing was examined after 5 and $10 \mathrm{~d}$ of autoclaving in carbonate or water at $270^{\circ} \mathrm{C}$ using a Nikon Eclipse LV $1503 \mathrm{D}$ microscope.

After the final compressive strength measurements, the cores and surfaces of the samples were ground into very fine powder and dried at $90^{\circ} \mathrm{C}$ for $24 \mathrm{~h}$ before thermogravimetric analyses, attenuated total reflectance Fourier transform infrared spectroscopy (ATR-FTIR) and x-ray diffractometric (XRD) characterisation. The samples were examined by taking four FTIR scans for each spectrum using a $40 \mathrm{kV}, 40 \mathrm{~mA}$ copper anode $\mathrm{x}$-ray tube with a $0.02^{\circ} \mathrm{step}, 1 \cdot 2 \% \mathrm{~min}$ scan speed, $2 \theta=3-51^{\circ}$.
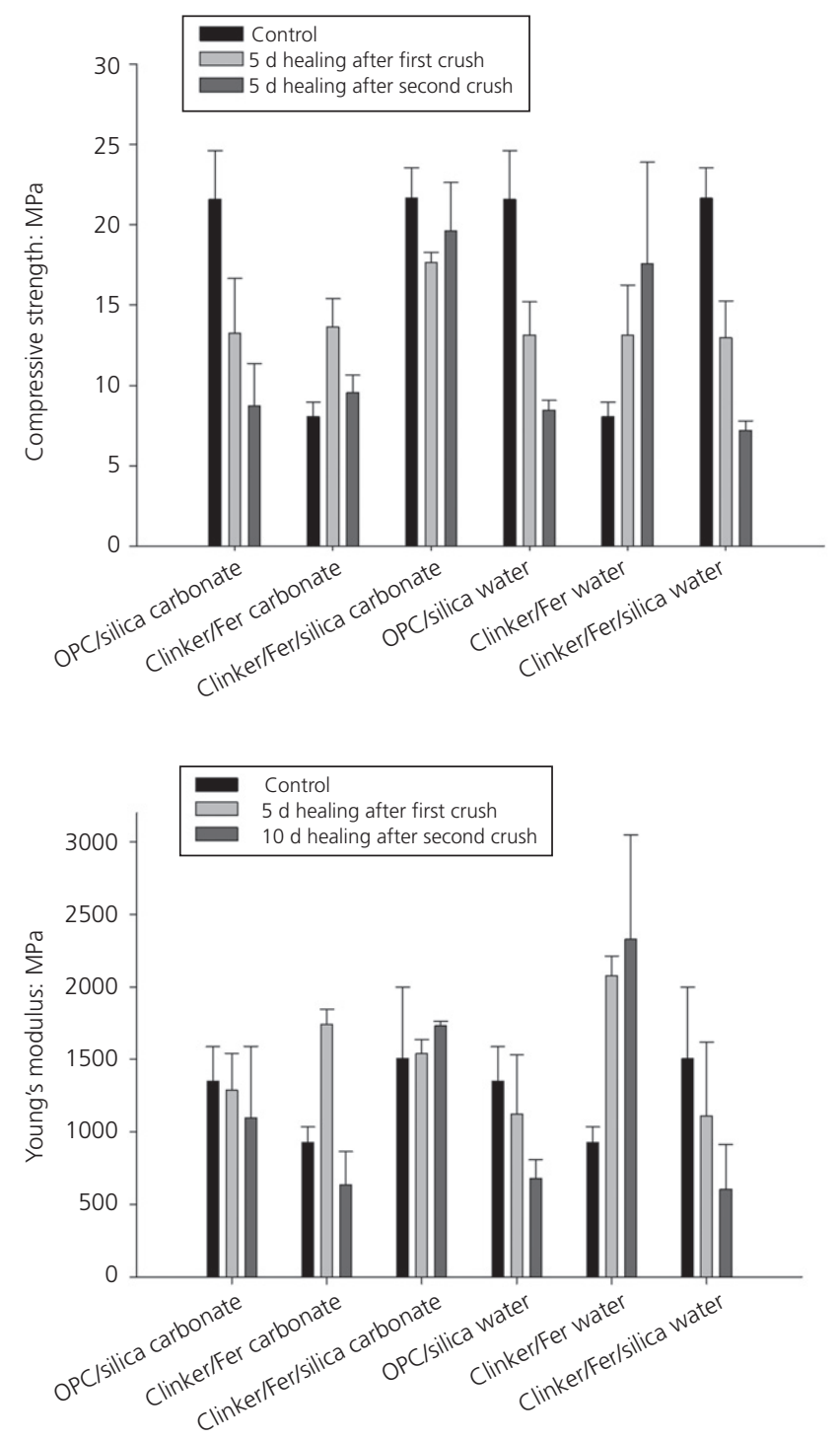

The results were analysed using the PDF-4/Minerals 2015 database of the International Center for Diffraction Data (ICDD). The morphologies of the selected formulations were explored on typical spots of freshly fractured and chromiumcoated samples with a Jeol $7600 \mathrm{~F}$ scanning electron microscope (accelerating voltage of $15 \cdot 0 \mathrm{kV}, 11 \mu \mathrm{A}$ ).

\section{Results and discussion}

\section{Mechanical properties and microscope study of} fracture filling

Figure 1 summarises the results of mechanical property measurements of samples of the silica-modified OPC and clinker/Fer blends. Outstanding compressive strength recoveries were achieved: $134 \%$ by the blend containing Fer without silica even after two crush tests in the water environment and
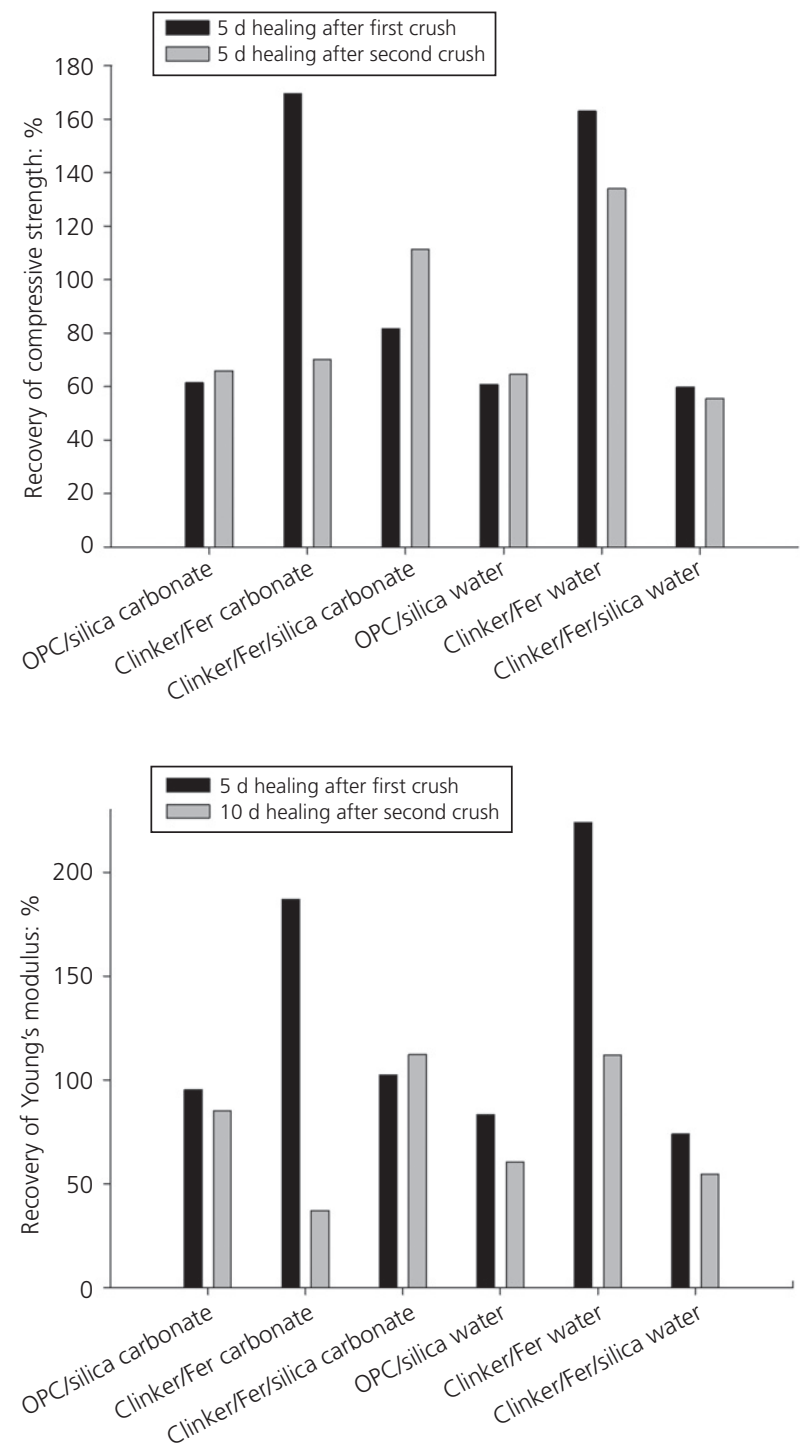

Figure 1. Mechanical properties and their recoveries in water or alkaline carbonate solution at $270^{\circ} \mathrm{C}$ for $\mathrm{OPC} /$ silica and clinker/Fer blends 


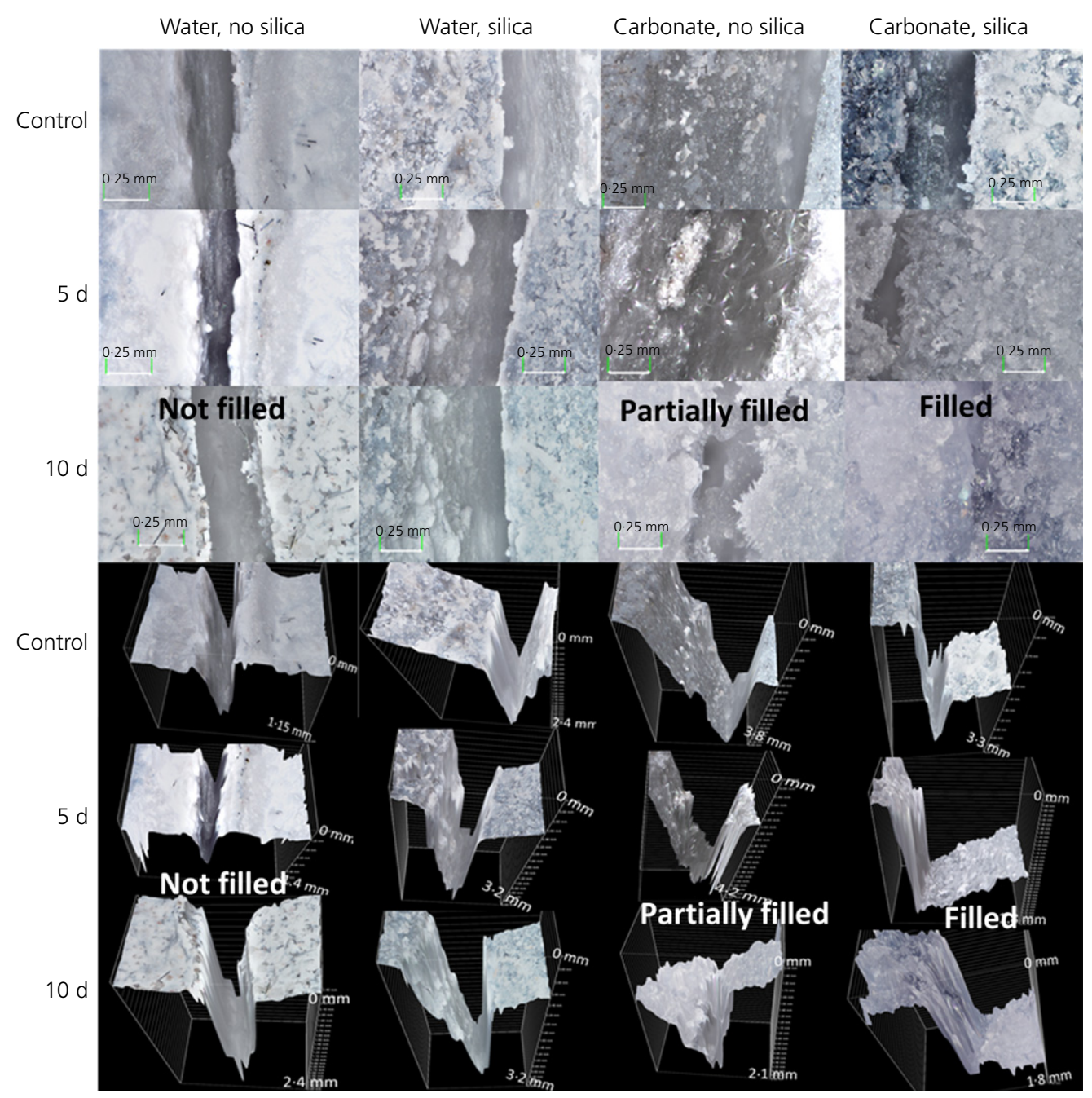

Figure 2. Photographs and 3D images of $0.25 \mathrm{~mm}$ crack in clinker/Fer silica-modified or non-modified samples before and after exposure to water or alkali carbonate environments at $270^{\circ} \mathrm{C}$ for $1 \mathrm{~d}$ (control), $5 \mathrm{~d}$ or $10 \mathrm{~d}$

$111 \%$ by the sample modified with silica in the carbonate environment. These compressive strength recoveries were accompanied by a progressive increase in Young's modulus, especially conspicuous for the sample without silica cured in water.

For the sample without silica cured in carbonate, the strength recovery was $170 \%$ after the first crush but only $70 \%$ after the second crush. The sample with silica cured in water showed strength recoveries very close to those of the OPC/silica blend (60\% after the first crush and 56\% after the second). The Young's modulus of these samples mirrored the compressive strength behaviour with strong recovery after the first crush and low recovery after the second crush for non-modified samples in carbonate and low recoveries for the sample with silica in water. Low strength recoveries were generally associated with the formation of large, long cracks.
Since the major role of a cement sheath in a subterranean well is zonal isolation, healed cement should possess low permeability along with recovered strength. The efficiency of crack filling was studied by taking images and reconstructing the $3 \mathrm{D}$ structure of pre-cracked $(0 \cdot 25 \mathrm{~mm}$ width) samples after 5 or $10 \mathrm{~d}$ of curing in water or carbonate (Figure 2). The crack filling was noticeably better in samples cured in the carbonate environment than those cured in water. For the sample modified with silica, the crack was completely sealed after $5 \mathrm{~d}$. The crack in the unmodified sample was partially filled after $10 \mathrm{~d}$ in carbonate solution, but additional curing time would complete the crack plugging. The water-healed samples had some minor solid depositions in the fractures but they were not sufficient to seal the large cracks.

The results clearly showed that the strength recovery and crack filling in the tested samples differed. Crack filling was 
unambiguously better in samples cured in carbonate than those in the water. The clinker/Fer sample modified with silica showed the best combination of strength recovery and fracture sealing when cured in the alkali carbonate environment.

\section{Analyses of degraded samples - crystalline phases and XRD patterns}

Tables 2-4 list the crystalline phases identified in the samples cured for $1 \mathrm{~d}$ (control), $5 \mathrm{~d}$ or $10 \mathrm{~d}$ in different environments, along with their ICDD numbers and chemical formulas. Figure 3 shows the XRD patterns of cores of the $10 \mathrm{~d}$ cured samples after water or carbonate solution curing (Figure 3(a)) and surfaces for carbonate-cured specimens (Figure 3(b)).

Both the control and $10 \mathrm{~d}$ cured samples showed some nonreacted clinker peaks $\left(\mathrm{C}_{3} \mathrm{~S}, \quad \mathrm{ICDD}\right.$ 04-014-9801; $\mathrm{C}_{2} \mathrm{~S}$, ICDD 00-033-0302) and peaks of crystalline silica for the silica-modified samples. The intensities of the residual clinker peaks were higher for the samples without silica and those cured in water compared against those cured in alkali carbonate (the dramatic difference in peak intensities at $\sim 2 \theta=29.4^{\circ}, 32 \cdot 2^{\circ}$ and $32.6^{\circ}$ could not be accounted for by the lower amount clinker in the silica-modified samples), indicating acceleration of clinker hydration by carbonate in the presence of silica. Fer peaks disappeared after $1 \mathrm{~d}$ of curing in all the specimens, suggesting fast alkaline decomposition of the zeolite.

After $10 \mathrm{~d}$ of curing, the major types of crystalline reaction products included: calcium silicates and aluminium-modified calcium silicate hydrates (CSHs) (xonotlite, tobermorite and aluminium-substituted tobermorite, pseudowollastonite (Mitsuda and Banno, 1977), kilchoanite); carbonated CSHs (scawtite and spurrite); magnesium (calcium, iron) silicates;

Table 2. Crystalline compositions of cements cured for $1 \mathrm{~d}$ (control)

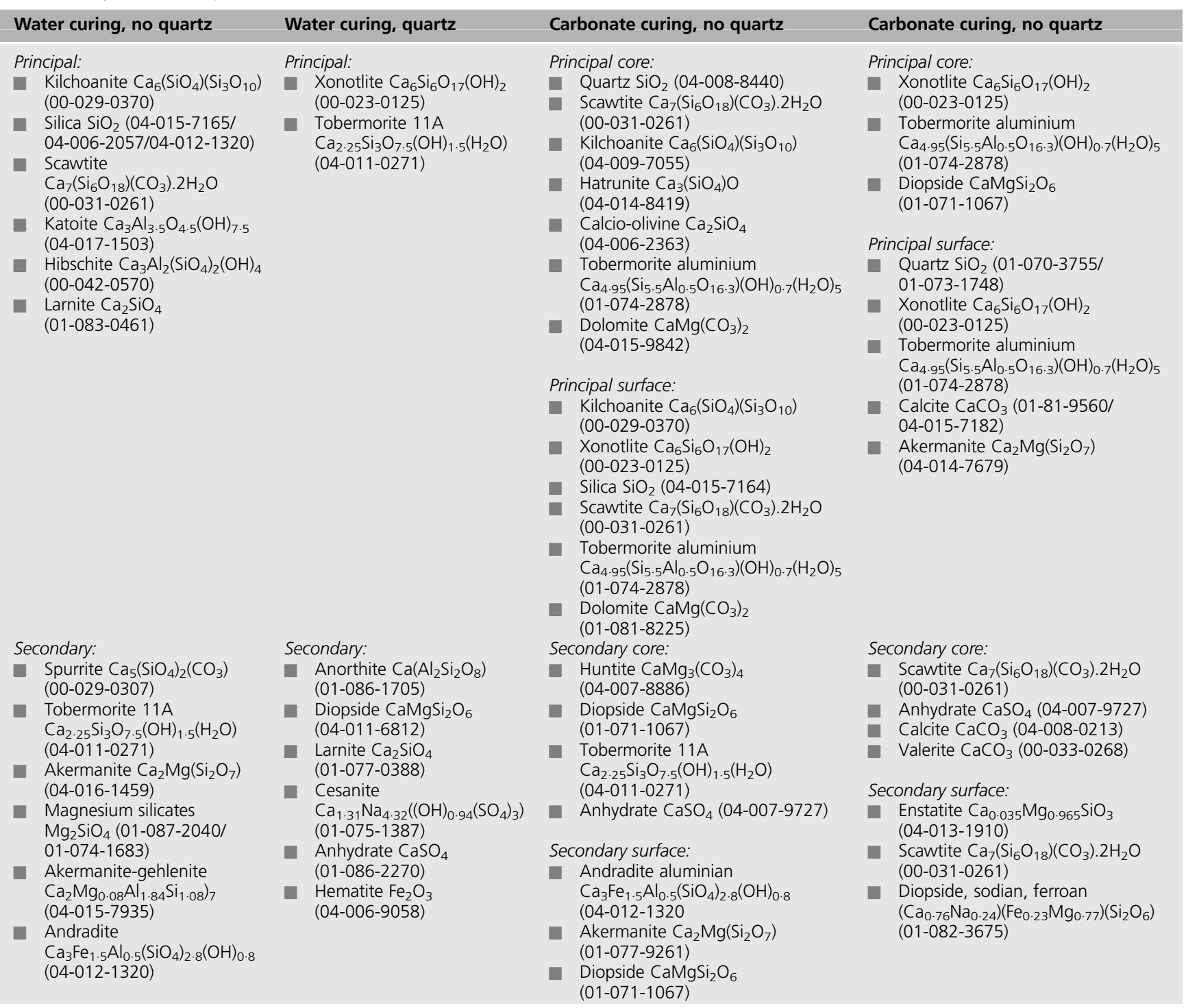


Table 3. Crystalline compositions of cements cured for $5 \mathrm{~d}$

\begin{tabular}{|c|c|c|c|}
\hline Water curing, no quartz & Water curing, quartz & Carbonate curing, no quartz & Carbonate curing, no quartz \\
\hline $\begin{array}{l}\text { Principal: } \\
\text { Xonotlite } \mathrm{Ca}_{6} \mathrm{Si}_{6} \mathrm{O}_{17}(\mathrm{OH})_{2} \\
(00-023-0125) \\
\text { Scawtite } \\
\mathrm{Ca}_{7}\left(\mathrm{Si}_{6} \mathrm{O}_{18}\right)\left(\mathrm{CO}_{3}\right) \cdot 2 \mathrm{H}_{2} \mathrm{O} \\
(00-042-1436) \\
\text { Coesite } \mathrm{SiO}_{2}(04-015-7168) \\
\text { Larnite } \mathrm{Ca}_{2} \mathrm{SiO}_{4} \\
(04-013-6293) \\
\text { Jarosite } \mathrm{KFe}_{3}\left(\mathrm{SO}_{4}\right)_{2}(\mathrm{OH})_{6} \\
(04-017-4421)\end{array}$ & $\begin{array}{l}\text { Principal: } \\
\quad \text { Xonotlite } \mathrm{Ca}_{6} \mathrm{Si}_{6} \mathrm{O}_{17}(\mathrm{OH})_{2} \\
(00-023-0125 / 04-017-1287) \\
\text { Tobermorite } 9 \mathrm{~A} \\
\mathrm{Ca}_{5} \mathrm{Si}_{6} \mathrm{O}_{16}(\mathrm{OH})_{2} \\
(04-012-1761) \\
\text { Tobermorite }-\mathrm{MDO} 2 \\
\mathrm{Ca}_{4.5} \mathrm{Si}_{6} \mathrm{O}_{16}(\mathrm{OH})\left(\mathrm{H}_{2} \mathrm{O}\right)_{5} \\
(04-017-1028)\end{array}$ & 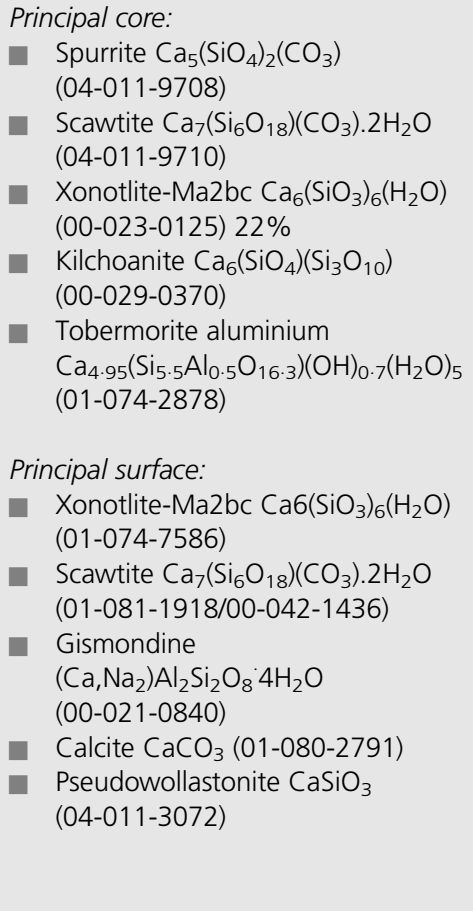 & $\begin{array}{l}\text { Principal core: } \\
\text { Xonotlite } \mathrm{Ca}_{6} \mathrm{Si}_{6} \mathrm{O}_{17}(\mathrm{OH})_{2} \\
(00-023-0125) \\
\text { Silica } \mathrm{SiO}_{2}(04-007-0522 / \\
01-075-8322) \\
\text { Tobermorite } \\
\mathrm{Ca}_{2 \cdot 25} \mathrm{Si}_{3} \mathrm{O}_{7 \cdot 5}(\mathrm{OH})_{1 \cdot 5}\left(\mathrm{H}_{2} \mathrm{O}\right) \\
(04-014-8455) \\
\text { Calcite } \mathrm{CaCO}_{3} \\
(04-019-3759 / 01-086-2340) \\
\text { Riversideite } \mathrm{Ca}_{5} \mathrm{Si}_{6} \mathrm{O}_{16}(\mathrm{OH})_{2} \\
(00-029-0329) \\
\\
\text { Principal surface: } \\
\text { Coesite } \mathrm{SiO}_{2}(04-015-7168) \\
\text { Tridymite-M SiO }{ }_{2} \\
(00-018-1170) \\
\text { Xonotlite } \mathrm{Ca}_{6} \mathrm{Si}_{6} \mathrm{O}_{17}(\mathrm{OH})_{2} \\
(00-023-0125) \\
\text { Scawtite } \mathrm{Ca}_{7}\left(\mathrm{Si}_{6} \mathrm{O}_{18}\right) \\
\left.(\mathrm{CO})_{3}\right) .2 \mathrm{H}_{2} \mathrm{O}(00-042-1436) \\
\text { Tobermorite } \\
\mathrm{Ca}_{2 \cdot 25} \mathrm{Si}_{3} \mathrm{O}_{7 \cdot 5}(\mathrm{OH})_{1 \cdot 5}\left(\mathrm{H}_{2} \mathrm{O}\right) \\
(04-014-8455) \\
\text { Lithosite } \mathrm{K}_{3}\left(\mathrm{HAl} \mathrm{Hi}_{2} \mathrm{Si}_{4} \mathrm{O}_{13}\right) \\
(01-073-8490)\end{array}$ \\
\hline $\begin{array}{l}\text { Secondary: } \\
\quad \text { Kilchoanite } \mathrm{Ca}_{6}\left(\mathrm{SiO}_{4}\right)\left(\mathrm{Si}_{3} \mathrm{O}_{10}\right) \\
(00-029-0370) \\
\text { Akermanite } \mathrm{Ca}_{2} \mathrm{Mg}\left(\mathrm{Si}_{2} \mathrm{O}_{7}\right) \\
(04-016-1459) \\
\text { Andradite aluminian } \\
\mathrm{Ca}_{3} \mathrm{Fe}_{1.5} \mathrm{Al}_{0.5}\left(\mathrm{SiO}_{4}\right)_{2 \cdot 8}(\mathrm{OH})_{0.8} \\
(04-012-1320) \\
\text { Calcite } \mathrm{CaCO}_{3}(01-080-2803) \\
\text { Bassanite } \mathrm{Ca}_{3}\left(\mathrm{SO}_{4}\right)_{3}\left(\mathrm{H}_{2} \mathrm{O}\right)_{1 \cdot 8} \\
(04-011-1766)\end{array}$ & $\begin{array}{l}\text { Secondary: } \\
\text { Diopside CaMgSi }{ }_{2} \mathrm{O}_{6} \\
\text { (04-015-8340) } \\
\text { Protoenstatite } \mathrm{MgSiO}_{3} \\
\text { (04-008-5467) } \\
\text { Clinoenstatite, calcian } \\
\mathrm{Mg}_{0.944} \mathrm{Ca}_{0.056} \mathrm{SiO}_{3} \\
(01-076-0525) \\
\text { Hedenbergite }\left(\mathrm{Fe}_{1.5} \mathrm{Ca}_{0.5}\right) \\
\left(\mathrm{Si}_{2} \mathrm{O}_{8}\right)(01-082-8083)\end{array}$ & $\begin{array}{l}\text { Secondary core: } \\
\text { Calcium carbonate } \mathrm{CaCO}_{3} \\
\text { (04-015-4109) } \\
\text { Andradite } \mathrm{Ca}_{3} \mathrm{Fe}_{2} \mathrm{Si}_{3} \mathrm{O}_{12} \\
(04-009-8467 / 01-073-6297) \\
\text { Andradite, aluminian } \\
\mathrm{Ca}_{3} \mathrm{Fe}_{1 \cdot 6} \mathrm{Al}_{0.4}\left(\mathrm{SiO}_{4}\right)_{2 \cdot 6}(\mathrm{OH})_{1 \cdot 6} \\
(04-012-1320) \\
\text { Pseudowollastonite } \mathrm{CaSiO}_{3} \\
(01-080-9543) \\
\text { Calcium magnesium silicate } \\
\mathrm{MgCa}\left(\mathrm{Si}_{2} \mathrm{O}_{6}\right)(01-076-6732) \\
\\
\text { Secondary surface: } \\
\text { Lawsonite } \mathrm{CaAl}\left(\mathrm{Si}_{2} \mathrm{O}_{7}\right)(\mathrm{OH})_{2}\left(\mathrm{H}_{2} \mathrm{O}\right) \\
(01-073-6449) \\
\text { Enstatite } \mathrm{Ca}_{0.035} \mathrm{Mg}_{0.965} \mathrm{SiO}_{3} \\
(04-013-1909) \\
\text { Cancrinite } \\
\text { Na } \mathrm{CaAl}_{6} \mathrm{Si}_{6}\left(\mathrm{CO}_{3}\right) \mathrm{O}_{24} \cdot 2 \mathrm{H}_{2} \mathrm{O} \\
(00-048-1862) \\
\text { Dolomite } \mathrm{CaMg}\left(\mathrm{CO}_{3}\right)_{2} \\
(00-011-0078)\end{array}$ & 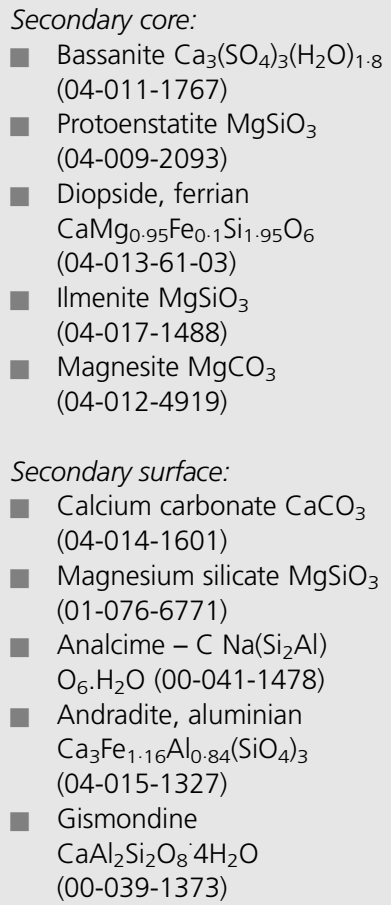 \\
\hline
\end{tabular}

magnesium and calcium carbonates; high-temperature-stable zeolites such as mordenite, analcime and thomsonite-calcium; calcium sulfates such as bassanite and anhydrate. Crystalline silica was dominant in the surfaces of specimens cured in alkali carbonate even for the unmodified samples.
The crystalline compositions of the silica-modified and unmodified samples varied noticeably. Calcium silicates with a calcium/silicon ratio between 0.7 and 1 (such as tobermorite and predominantly xonotlite) formed as the major crystalline products in both environments for samples modified with 
Table 4. Crystalline compositions of cements cured for $10 \mathrm{~d}$

\begin{tabular}{|c|c|c|c|}
\hline Water curing, no quartz & Water curing, quartz & Carbonate curing, no quartz & Carbonate curing, no quartz \\
\hline $\begin{array}{l}\text { Principal: } \\
\text { Orthoenstatite } \\
(01-082-3784) \mathrm{MgSiO}_{3} \\
\text { Xonotlite } \mathrm{Ca}_{6} \mathrm{Si}_{6} \mathrm{O}_{17}(\mathrm{OH})_{2} \\
(00-023-0125) \\
\text { Scawtite } \\
\mathrm{Ca}_{7}\left(\mathrm{Si}_{6} \mathrm{O}_{18}\right)\left(\mathrm{CO}_{3}\right) \cdot 2 \mathrm{H}_{2} \mathrm{O} \\
(00-042-1436) \\
\text { Spurrite } \mathrm{Ca}_{5}\left(\mathrm{SiO}_{4}\right)_{2}\left(\mathrm{CO}_{3}\right) \\
(04-011-9708) \\
\text { Kilchoanite } \\
\mathrm{Ca}_{6}\left(\mathrm{SiO}_{4}\right)\left(\mathrm{Si}_{3} \mathrm{O}_{10}\right) \\
(00-029-0370) \\
\text { Andradite aluminian } \\
\text { Ca } \mathrm{Ca}_{1.5} \mathrm{Al}_{0.5}\left(\mathrm{SiO}_{4}\right)_{2 \cdot 8}(\mathrm{OH})_{0.8} \\
(04-012-1320) \\
\text { Jarosite } \mathrm{KFe}_{3}\left(\mathrm{SO}_{4}\right)_{2}(\mathrm{OH})_{6} \\
(04-017-4421)\end{array}$ & $\begin{array}{l}\text { Principal: } \\
\text { Xonotlite } \mathrm{Ca}_{6} \mathrm{Si}_{6} \mathrm{O}_{17}(\mathrm{OH})_{2} \\
(04-017-1287) \\
\text { Pseudowollastonite } \mathrm{CaSiO}_{3} \\
(04-011-3072)\end{array}$ & $\begin{array}{l}\text { Principal core: } \\
\text { Spurrite } \mathrm{Ca}_{5}\left(\mathrm{SiO}_{4}\right)_{2}\left(\mathrm{CO}_{3}\right) \\
(04-011-9708) \\
\text { Scawtite } \mathrm{Ca}_{7}\left(\mathrm{Si}_{6} \mathrm{O}_{18}\right)\left(\mathrm{CO}_{3}\right) \cdot 2 \mathrm{H}_{2} \mathrm{O} \\
(01-081-1918) \\
\text { Xonotlite- } \mathrm{Ma}_{2} \mathrm{bc} \mathrm{Ca}_{6}\left(\mathrm{SiO}_{3}\right)_{6}\left(\mathrm{H}_{2} \mathrm{O}\right) \\
\text { (01-074-7583) } \\
\text { Pseudowollastonite } \mathrm{CaSiO}_{3} \\
(01-080-9543) \\
\text { Calcite } \mathrm{CaCO}_{3}(01-078-3262) \\
\\
\text { Principal surface: } \\
\text { SiO } \\
2191 / 04-017-1027-004-7249 / 04-007- \\
\text { 7824/04-013-9484/04-007-2468) } \\
\text { Talc-1A } \mathrm{Mg}_{3} \mathrm{Si}_{4} \mathrm{O}_{10}(\mathrm{OH})_{2} \\
(04-013-2941) \\
\text { Mordenite } \mathrm{Na}_{3} \mathrm{Al}_{3} \mathrm{Si}_{21} \mathrm{O}_{48}\left(\mathrm{H}_{2} \mathrm{O}\right)_{9 \cdot 2} \\
(04-017-1315)\end{array}$ & $\begin{array}{l}\text { Principal core: } \\
\text { Xonotlite-Ma2b2c } \\
\mathrm{Ca}_{6} \mathrm{Si}_{6} \mathrm{O}_{18}\left(\mathrm{H}_{2} \mathrm{O}\right) \\
(01-074-7584) \\
\mathrm{SiO}_{2}(01-075-8322 / 01- \\
\text { 072-4568/04-008-8696) } \\
\text { Pseudowollastonite } \\
\text { (04-011-3072) } \mathrm{CaSiO}_{3} \\
\text { Tobermorite } \\
\mathrm{Ca}_{2 \cdot 25} \mathrm{Si}_{3} \mathrm{O}_{7.5}(\mathrm{OH})_{1.5}\left(\mathrm{H}_{2} \mathrm{O}\right) \\
(04-014-8455) \\
\text { Calcite } \mathrm{CaCO}_{3} \\
(01-081-9560) \\
\\
\text { Principal surface: } \\
\text { SiO } \mathrm{O}_{2}(01-089-3607 / \\
04-012-1126 / \\
01-077-8631) 49 \% \\
\text { Xonotlite } \mathrm{Ca}_{6} \mathrm{Si}_{6} \mathrm{O}_{17}(\mathrm{OH})_{2} \\
(00-023-0125) \\
\text { Talc-1A } \mathrm{Mg}_{3} \mathrm{Si}_{4} \mathrm{O}_{10}(\mathrm{OH})_{2} \\
(04-013-2941)\end{array}$ \\
\hline $\begin{array}{l}\text { Secondary: } \\
\begin{aligned} & \text { Bassanite } \\
& \mathrm{Ca}_{3}\left(\mathrm{SO}_{4}\right)_{3}\left(\mathrm{H}_{2} \mathrm{O}\right)_{1 \cdot 8} \\
&(04-011-1766) \\
& \text { Anhydrate } \mathrm{CaSO}_{4} \\
&(04-007-9727) \\
& \text { Magnesite } \mathrm{MgCO}_{3} \\
&(04-012-4918)\end{aligned}\end{array}$ & $\begin{array}{l}\text { Secondary: } \\
\text { Anorthite } \mathrm{Ca}\left(\mathrm{Al}_{2} \mathrm{Si}_{2} \mathrm{O}_{8}\right) \\
(01-086-1705) \\
\text { Diopside aluminian } \\
\left(\mathrm{Ca}_{0.5}\left(\mathrm{Ca}_{0} \cdot \mathrm{Mg}_{0 \cdot 1}\right)\right) \\
\left(\mathrm{Mg}_{0.86} \mathrm{Al}_{0 \cdot 14}\right)\left(\mathrm{Al}_{0 \cdot 15} \mathrm{Si}_{1 \cdot 85} \mathrm{O}_{6}\right) \\
(01-075-9999) \\
\text { Tobermorite } \\
11 \mathrm{~A} \mathrm{Ca}_{4}\left(\mathrm{Si}_{6} \mathrm{O}_{15}\right)(\mathrm{OH})_{2}\left(\mathrm{H}_{2} \mathrm{O}\right)_{5} \\
(01-077-8367) \\
\text { Magnesite } \mathrm{MgCO} \mathrm{CO}_{3} \\
(04-012-4918) \\
\text { Calcium magnesium silicate } \\
\text { Ca } \mathrm{Mg}_{2}\left(\mathrm{Si}_{2} \mathrm{O}_{7}\right)(04-014-7678) \\
\text { Bassanite } \mathrm{Ca}_{3}\left(\mathrm{SO}_{4}\right)_{3}\left(\mathrm{H}_{2} \mathrm{O}\right)_{1 \cdot 8} \\
(04-011-1767) \\
\text { Anhydrate } \mathrm{CaSO}_{4} \\
(04-007-9727) \\
\text { Scawtite } \mathrm{Ca}_{7} \mathrm{Si}_{6}\left(\mathrm{CO}_{3}\right) \mathrm{O}_{18} 2 \mathrm{H}_{2} \mathrm{O} \\
(00-042-1436)\end{array}$ & $\begin{array}{l}\text { Secondary core: } \\
\text { Andradite aluminian } \\
\mathrm{Ca}_{3} \mathrm{Fe}_{1.5} \mathrm{Al}_{0.5}\left(\mathrm{SiO}_{4}\right)_{2 \cdot 8}(\mathrm{OH})_{0 \cdot 8} \\
(04-012-1320) \\
\text { Thomsonite } \mathrm{Ca} \\
\mathrm{NaCa}_{2} \mathrm{Al}_{5} \mathrm{Si}_{5} \mathrm{O}_{20}\left(\mathrm{H}_{2} \mathrm{O}\right)_{6} \\
(04-013-3051) \\
\\
\text { Secondary surface: } \\
\text { Xonotlite } \mathrm{Ca}_{6} \mathrm{Si}_{6} \mathrm{O}_{17}(\mathrm{OH})_{2} \\
(00-023-0125) \\
\text { Analcime } \mathrm{Na}\left(\mathrm{AlSi}_{2} \mathrm{O}_{6}\right)\left(\mathrm{H}_{2} \mathrm{O}\right) \\
(01-072-0445) \\
\text { Tobermorite }-\mathrm{MDO} 1 \\
\text { Ca } \mathrm{Si}_{6} \mathrm{O}_{15}(\mathrm{OH})_{2}\left(\mathrm{H}_{2} \mathrm{O}\right)_{5} \\
(04-017-1027)\end{array}$ & $\begin{array}{l}\text { Secondary core: } \\
\text { Calcium magnesium } \\
\text { silicate (diopside) } \\
\text { CaMgSi } \mathrm{O}_{6}(04-011-6812) \\
\text { Calcium magnesium } \\
\text { silicate } \mathrm{Ca}_{2} \mathrm{Mg}\left(\mathrm{Si}_{2} \mathrm{O}_{7}\right) \\
(04-014-7678) \\
\text { Anhydrate } \mathrm{CaSO}{ }_{4} \\
(01-072-0916) \\
\\
\text { Secondary surface: } \\
\text { Mordenite } \\
\mathrm{Na}_{3} \mathrm{Al}_{3} \mathrm{Si}_{21} \mathrm{O}_{48}\left(\mathrm{H}_{2} \mathrm{O}\right)_{9 \cdot 2} \\
(04-017-1315) \\
\mathrm{Magnesium} \text { iron silicate } \\
\mathrm{MgFe}\left(\mathrm{SiO}_{4}\right)(04-014-7729)\end{array}$ \\
\hline
\end{tabular}

silica. Tobermorite persisted up to $10 \mathrm{~d}$ of curing and its calcium-to-silica content decreased as the curing time in carbonate solution increased, suggesting calcium removal through carbonation. Aluminium dissociated from decomposed Fer was included in tobermorite detected in the control samples in the carbonate environment. In addition to aluminium, zeolite decomposition supplied silicon and magnesium for further reactions.

The crystalline composition of the silica-rich samples cured in water closely resembled those of the OPC/silica blend, with the principal products being the clinker high-temperature hydrates.

In the case of unmodified samples, kilchoanite and dicalcium silicate were the major CSHs with calcium/silicon ratios of 1.5 and 2, respectively, formed after $1 \mathrm{~d}$ at $270^{\circ} \mathrm{C}$ (control). The hydrothermal formation of dicalcium silicates and transformation to kilchoanite at temperatures above $220^{\circ} \mathrm{C}$ were reported by Mitsuda et al. (1985). Kilchoanite persisted in the watercured samples after $10 \mathrm{~d}$, coexisting with xonotlite, which became the major calcium silicate phase in both the waterand carbonate-cured samples.

Carbonated CSHs were the main hydration products in the absence of silica in both the water-cured samples and especially in the carbonate-cured samples. They formed in the control samples and the intensity of their peaks steadily increased at the longer curing times of $5 \mathrm{~d}$ and then $10 \mathrm{~d}$. These were scawtite and spurrite, possibly contributing to the increased crack sealing rate (see the section on 'Mechanical properties and 


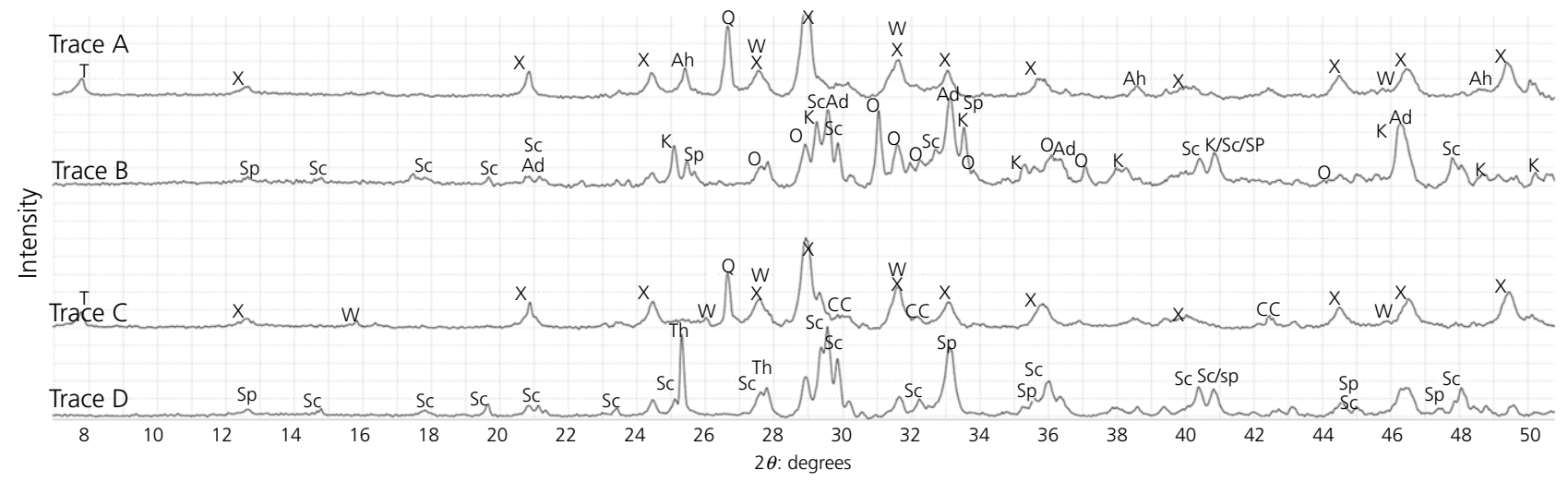

(a)



(b)

Figure 3. XRD patterns of clinker/Fer blends after curing for $10 \mathrm{~d}$ at $270^{\circ}$. (a) Sample cores: trace A, silica-modified sample cured in water; trace $B$, non-modified sample cured in water; trace $C$, silica-modified sample cured in carbonate; trace $D$ non-modified sample cured in carbonate. (b) Sample surfaces: trace A, silica-modified sample cured in carbonate; trace B non-modified sample cured in carbonate. $\mathrm{T}=$ tobermorite, $\mathrm{X}=$ xonotlite, $\mathrm{O}=$ orthoenstatite, $\mathrm{K}=$ kilchoanite, $\mathrm{Sc}=$ scawtite, $\mathrm{Sp}=$ spurrite, $\mathrm{Th}=$ thomsonite, $\mathrm{Ad}=$ andradite aluminian, $\mathrm{Ah}=$ anhydrate, $\mathrm{Q}=$ quartz, $\mathrm{CC}=$ calcium carbonates, $\mathrm{An}=$ analcime, $\mathrm{Mo}=$ mordenite, $\mathrm{TC}=$ talc

microscope study of fracture filling'). The hydrothermal formation of carbonated calcium silicates from dicalcium silicate and silica has been reported previously (Kalousek and Nelson, 1978). Scawtite persists under high-temperature hydrothermal conditions; it was found to be present in natural rocks exposed to carbonates, forming a stable layer during the carbonation of CSH-bearing rocks from Northern Ireland (Milodowski et al., 2011). It was also reported to be commonly encountered in high-temperature wells where aqueous solutions of carbon dioxide entering pores of hydrating cement form scawtite and release silica that may partially seal fractures (Bensted, 1988).

Decomposed Fer was the main source of magnesium while clinker provided calcium for calcium magnesium silicates crystallised after the first day of curing (akermanite, diopside and enstatite). At longer curing times in the alkali carbonate solution, the intensities of their peaks strongly decreased even in cores of the samples, likely because of calcium removal through carbonation. Dolomite crystallised as one of the principal phases in unmodified samples through the calcium hydroxide attack of Fer, but its peaks weakened strikingly after $5 \mathrm{~d}$ of curing and were completely replaced by talc in the surfaces after $10 \mathrm{~d}$ through skarnification reactions with silica accompanied by calcium carbonate formation, which was a major crystalline phase in the surface of the unmodified samples. Talc is a soft, clay-type mineral, and is unlikely to play any significant role in strength recovery; however, it may aid the sealing of small crevices.

In the case of the water-cured silica-modified samples, calcium magnesium silicate formed after $1 \mathrm{~d}$ of curing and persisted in the samples for $10 \mathrm{~d}$. However, the peak intensities of this product were significantly lower than those of calcium silicates, indicating that this phase was not a major contributor to the strength recovery. In the sample without silica, magnesium silicate formed after the first day and became a major crystalline hydration product after $10 \mathrm{~d}$. This phase likely played the key role in the outstanding strength recovery of the unmodified water-cured sample.

High-temperature-stable zeolites formed mostly in the surface layer of carbonate-cured specimens after $10 \mathrm{~d}$ of curing. In the presence of silica, the silica-rich zeolite mordenite was predominant (silicon/aluminium ratio $=7$ ). For the sample without silica, peaks of thomsonite-calcium with lower silica content 
were detected (silicon/aluminium ratio $=1$ ). Notably, there were no zeolites among the principal core products in any of the specimens. Zeolites could be crystallising from the silica aluminate amorphous phase after the decomposition of Fer and magnesium reactions with calcium, silica and carbonate or could crystallise from solution with high dissolved sodium, aluminium and silicon contents at the solids' surfaces. In both cases, sodium and carbonate ions of the solution would play a major role in zeolite crystallisation, explaining their presence in the surfaces of the samples.

Some iron-containing hydrates formed, with the iron associated with Fer, and likely assisted in strength recovery. After $10 \mathrm{~d}$ of curing, they included andradite aluminian in both environments and magnesium iron silicate in the surface of the modified samples cured in carbonate solution.

In summary, the XRD analyses showed high-temperature alkaline Fer decomposition after $1 \mathrm{~d}$ of curing, the persistence of unreacted clinker and silica phases for $10 \mathrm{~d}$ and faster clinker loss for the silica-modified samples cured in alkali carbonate. The reactions of calcium from the clinker with magnesium from the Fer led to the formation of calcium magnesium silicates or dolomite. These products were not stable in the carbonate solution, transforming to calcium-free magnesium silicates and talc at longer curing times. The major identified crystalline phases contributing to the strength recovery were calcium silicates (xonotlite, tobermorite, kilchoanite and pseudowollastonite), magnesium silicate (orthoenstatite) and calcium iron aluminate (andradite). The phases participating in sealing the cracks were mostly formed in the carbonate environment and included crystalline silica, talc and high-temperature-stable zeolites (mordenite, analcime and thomsonite-calcium). Carbonated calcium silicates, scawtite and spurrite, formed in unmodified samples as principal phases in the sample cured in carbonate and to a lesser extent in the water-cured samples, contributing to the strength when present in small amounts. Sodium carbonate played an important role in the formation of reaction/hydration products stable after $10 \mathrm{~d}$ of curing through the interactions of calcium, magnesium, sodium, carbonate and bicarbonate ions, creating conditions favouring silica precipitation.

\section{Differential thermogravimetric (DTG) measurements}

Table 5 lists the weight losses in different temperature ranges for specimens cured in water and carbonate solution and Figure 4 shows the DTG curves for the control samples (cured for $24 \mathrm{~h}$ at $270^{\circ} \mathrm{C}$ ) and the samples cured for $10 \mathrm{~d}$. The weight losses up to $400^{\circ} \mathrm{C}$ can be associated with (sodium, calcium) silica aluminate and $\mathrm{CSH}$; zeolite decomposition may also contribute to the weight loss in that temperature range (analcime, mordenite and thomsonite (Foldvari, 2011)). Between about 400 and $550^{\circ} \mathrm{C}$, calcium-rich $\mathrm{CSHs}$ contribute to the weight loss (Ishida et al., 1993), along with calcium hydroxide; the recrystallisation of aragonite to calcite occurs at around
Table 5. Thermal decomposition temperature ranges and associated weight losses for specimens cured under different conditions

\begin{tabular}{|c|c|c|c|}
\hline \multirow[b]{2}{*}{ Sample } & \multicolumn{3}{|c|}{ Weight loss: \% } \\
\hline & $70-400^{\circ} \mathrm{C}$ & $400-550^{\circ} \mathrm{C}$ & $600-850^{\circ} \mathrm{C}$ \\
\hline \multicolumn{4}{|c|}{ Water curing, no quartz } \\
\hline $1 \mathrm{~d}$ (control) & $2 \cdot 7$ & 1.6 & $3 \cdot 4$ \\
\hline $10 d$ & $1 \cdot 5$ & $1 \cdot 4$ & $3 \cdot 3$ \\
\hline \multicolumn{4}{|c|}{ Water curing, quartz } \\
\hline $1 \mathrm{~d}$ (control) & $4 \cdot 1$ & $1 \cdot 0$ & $2 \cdot 5$ \\
\hline $10 \mathrm{~d}$ & $3 \cdot 8$ & 0.8 & $2 \cdot 4$ \\
\hline \multicolumn{4}{|c|}{ Carbonate curing, no quartz } \\
\hline $1 \mathrm{~d}$ (control) & $2 \cdot 7$ & 1.6 & $4 \cdot 8$ \\
\hline $10 d$ & 1.4 & $1 \cdot 2$ & $8 \cdot 2$ \\
\hline \multicolumn{4}{|c|}{ Carbonate curing, quartz } \\
\hline $1 \mathrm{~d}$ (control) & $4 \cdot 2$ & $0 \cdot 7$ & $3 \cdot 0$ \\
\hline $10 \mathrm{~d}$ & $3 \cdot 6$ & 0.6 & $3 \cdot 0$ \\
\hline
\end{tabular}

$450^{\circ} \mathrm{C}$. The weight losses at temperatures above $550^{\circ} \mathrm{C}$ are, for the most part, due to the decomposition of carbonates such as calcite $\left(\sim 600^{\circ} \mathrm{C}\right)$, magnetite $\left(\sim 620-650^{\circ} \mathrm{C}\right)$, calcium magnesium carbonates $\left(600-650^{\circ} \mathrm{C}\right.$, huntite), magnesium iron calcium carbonate $\left(\sim 700-750^{\circ} \mathrm{C}\right)$ and dolomite $\left(750-800^{\circ} \mathrm{C}\right)$ (Foldvari, 2011). Calcium silicate carbonate, scawtite, decomposes to $\mathrm{CaCO}_{3}$ at $\sim 790^{\circ} \mathrm{C}$ and de-carbonates in the temperature range between $\sim 830$ and $850^{\circ} \mathrm{C}$ (McConnell, 1955; Stevula and Petrovic, 1981). The sulfate-containing mineral jarosite decomposes at $\sim 610^{\circ} \mathrm{C}$ (Frost et al., 2005) contributing to the mass loss in the range $550-850^{\circ} \mathrm{C}$ for the water-cured unmodified samples. Talc decomposition also takes place in this temperature range $\left(\sim 800-840^{\circ} \mathrm{C}\right)$ (Ewell et al., 1935).

The decomposition peaks of various hydrates overlap strongly, thus not allowing the identification of separate phases. However, the following general trends supported the findings of the XRD analysis. The weight losses below $400^{\circ} \mathrm{C}$ were about twice as high for the samples with silica as for those without it in both water and carbonate curing environments, confirming the formation of $\mathrm{CSH}$ in the presence of silica and faster clinker reactions for the silica-modified samples. On the other hand, the decomposition rate in the range $400-550^{\circ} \mathrm{C}$ associated with the calcium-rich hydrates and calcium hydroxide was greater for the samples without silica $(0 \cdot 6-1 \cdot 0 \%$ with silica; $1 \cdot 2-1 \cdot 6 \%$ without silica). These hydrates are likely to be amorphous for the most part with some contribution of kilchoanite, as identified by XRD. The specimen without silica cured in the carbonate solution experienced the greatest weight loss above $550^{\circ} \mathrm{C}(>8 \%)$. This result is in agreement with the XRD study, suggesting the decomposition of carbonated calcium silicate (scawtite) along with the possible decompositions of dolomite and talc (a wide decomposition band above $800^{\circ} \mathrm{C}$ ). The decomposition peaks of silicacontaining specimens at $\sim 785^{\circ} \mathrm{C}$ are likely associated with calcium magnesium carbonates. 

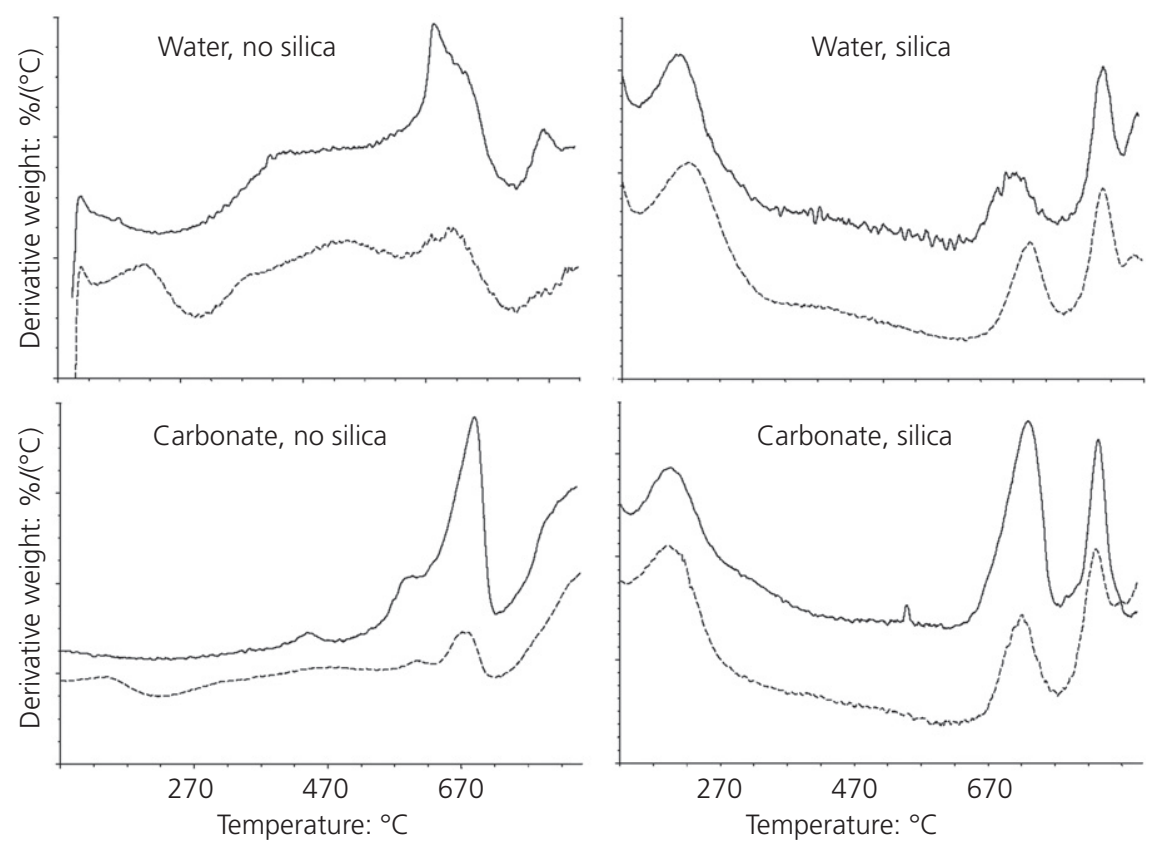

Figure 4. DTG curves of cement blends cured for $1 \mathrm{~d}$ (control; dashed lines) or $10 \mathrm{~d}$ (after two crush tests; solid lines) at $270^{\circ} \mathrm{C}$ in water or alkali carbonate solution

\section{ATR-FTIR measurements}

Figure 5(a) shows the FTIR absorption spectra in the region of 1800 to $650 \mathrm{~cm}^{-1}$ for the water-cured control samples $(24 \mathrm{~h}$ at $270^{\circ} \mathrm{C}$ ) and for the non-hydrated clinker/Fer blend. The spectrum of the blend encompassed the following 11 absorption bands.

- A wide band around $1043 \mathrm{~cm}^{-1}$ and a weak one at $669 \mathrm{~cm}^{-1}$ from $\mathrm{T}-\mathrm{O}(\mathrm{T}=$ silicon or aluminium $)$ bond-related anti-symmetric ( $V_{\text {as T-O }}$ ) and symmetric $\left(V_{\mathrm{s}} \mathrm{T}-\mathrm{O}\right)$ stretching vibrations in $3 \mathrm{D}$ oxygen-linked $\left[\mathrm{SiO}_{4}\right]^{4-}$ and $\left[\mathrm{AlO}_{4}\right]^{5-}$ tetrahedral frameworks of zeolite.

- Two other bands of T-O bonds at $1225\left(\mathrm{Si}-\mathrm{O}\left(V_{\text {as } \mathrm{Si}-\mathrm{O}}\right)\right)$ and $707 \mathrm{~cm}^{-1}$ (Al-O $\left.\left(V_{\mathrm{s} \mathrm{Al}-\mathrm{O}}\right)\right)$ (Christidis et al., 2003; Elaiopoulos et al., 2010; Joshi et al., 1997; Mozgawa, 2001).

- The prominent doublet at 921 and $889 \mathrm{~cm}^{-1}$ from the cement clinkers, namely, $\mathrm{Si}-\mathrm{O}$ bond stretching $\left(V_{\text {as }} \mathrm{Si-O}\right)$ in orthosilicate of calcium silicates $\left(\mathrm{C}_{3} \mathrm{~S}\right.$ and $\left.\mathrm{C}_{2} \mathrm{~S}\right)$, and the band at $707 \mathrm{~cm}^{-1}$ from Al-O $\left(V_{\mathrm{s} \text { Al-O }}\right)$ in tricalcium aluminate $\left(\mathrm{C}_{3} \mathrm{~A}\right)$ (Fernandez-Carrasco et al., 2012; Gaki et al., 2007; Mollah et al., 2000; Taddei et al., 2014).

- The five bands at 1486, 1451, 853, 829 and $707 \mathrm{~cm}^{-1}$ associated with the carbonate $\left(\mathrm{CO}_{3}^{2-}\right)$ group in carbonated compounds: the two bands at 1486 and $1451 \mathrm{~cm}^{-1}$ from $\mathrm{C}-\mathrm{O}$ bond stretching $\left(V_{\text {as C-O }}\right)$ and the last three bands from $\mathrm{O}-\mathrm{C}-\mathrm{O}$ bond bending $\left(\delta_{\mathrm{O}-\mathrm{C}-\mathrm{O}}\right)$ (Gunasekaran et al., 2006; Xyla and Koutsoukos, 1989; Ylmen and Jaglid, 2013), so both Al-O and C-O contributed to the $707 \mathrm{~cm}^{-1}$ band. The shoulder and weak bands at 1158 and $669 \mathrm{~cm}^{-1}$, respectively, are attributable to $\mathrm{S}-\mathrm{O}$ stretching $\left(V_{\text {as S-O}}\right)$ and $\mathrm{O}-\mathrm{S}-\mathrm{O}$ bending $\left(\delta_{\text {as }} \mathrm{O}-\mathrm{S}-\mathrm{O}\right)$ of the sulfate $\left(\mathrm{SO}_{4}^{2-}\right)$ tetrahedral group in gypsum (Fernandez-Carrasco et al., 2012; García-Lodeiro et al., 2011; Ylmen et al., 2009). Finally, the band at $1624 \mathrm{~cm}^{-1}$ was from $\mathrm{H}-\mathrm{O}-\mathrm{H}$ bending $\left(\delta_{\mathrm{H}-\mathrm{O}-\mathrm{H}}\right)$ in water.

The spectrum of the cement autoclaved in water for $24 \mathrm{~h}$ at $270^{\circ} \mathrm{C}$ showed the following new features: $(a)$ the appearance of three new bands at 1204, 1073 and $959 \mathrm{~cm}^{-1}$; $(b)$ the attenuation in absorbance and disappearance of Fer-related bands (Otero Areán et al., 2008); (c) the enhanced peak intensity of carbonate-associated bands. The new band at $1204 \mathrm{~cm}^{-1}$ was attributed to $\mathrm{Si}-\mathrm{O}$ stretching $\left(V_{\text {as } \mathrm{Si}-\mathrm{O}}\right)$ in the amorphous silica gel (Almecida and Pantano, 1990) and the other two new bands were $\mathrm{Si}-\mathrm{O}\left(V_{\text {as }} \mathrm{Si-O}\right)$ in $\mathrm{CSH}$ and calcium silicate anhydrate formed during $\mathrm{C}_{3} \mathrm{~S}$ and $\mathrm{C}_{2} \mathrm{~S}$ hydration (Mollah et al., 2000; Taddei et al., 2014), resulting in the band frequency shift from $921 \mathrm{~cm}^{-1}$ of orthosilicate to $959 \mathrm{~cm}^{-1}$ of polymerised silicate.

The attenuation in absorbance and the disappearance of Fer-related bands strongly suggested zeolite decomposition in reactions, with $\mathrm{Ca}^{2+}$ and $\mathrm{OH}^{-}$released during clinker hydration under high-temperature hydrothermal conditions (Collepardi et al., 1976; Costa and Massazza, 1977). As a result of hot alkali dissolution and hydrothermal disintegration, Fer partially disappeared and partially converted to an amorphous phase. 
Advances in Cement Research Volume 30 Issue 1
Self-repairing properties of OPC

clinker/natural zeolite blend in water and

alkali carbonate environments at $270^{\circ} \mathrm{C}$

Pyatina, Sugama, Ronne and Trabits
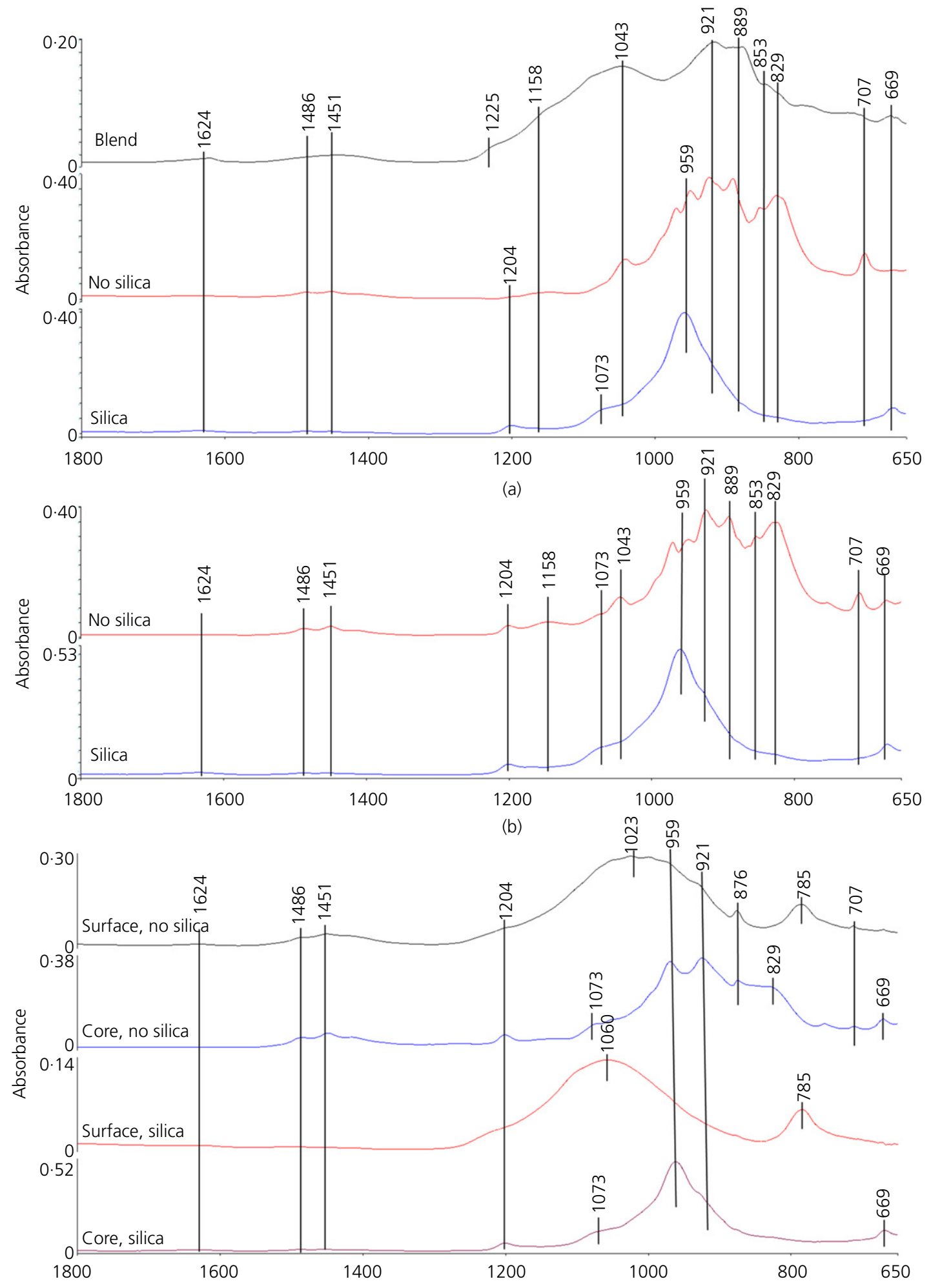

(c)

Wavenumber: $\mathrm{cm}^{-1}$

Figure 5. FTIR spectra of non-hydrated clinker/Fer blend, and control samples cured for $1 \mathrm{~d}(\mathrm{a})$ or $10 \mathrm{~d}(\mathrm{~b})$ in water at $270^{\circ} \mathrm{C}$; samples cured in alkali carbonate solution at $270^{\circ} \mathrm{C}$ for $10 \mathrm{~d}$ (c) 
The enhanced intensity of carbonate-associated bands corresponds to a large amount of carbonated CSH such as scawtite formed in cement. As is obvious from the presence of bands at 921 and $889 \mathrm{~cm}^{-1}$, some non-hydrated clinker still remained after autoclaving for $1 \mathrm{~d}$. This fact was one of the reasons why the non-modified samples had a lower compressive strength at an early hydration age. However, importantly, cement damaged in the crush tests recovered its compressive strength during an extended autoclave period, at least partially because of the hydration of non-reacted clinker. Additionally, the bands at 1158 and $669 \mathrm{~cm}^{-1}$ were interpreted as sulfate-related reaction products (Al-Hosney and Grassian, 2005; Thompson and Palmer, 1988).

The spectrum of the silica-modified sample clearly differed from that of the unmodified sample with even more striking decay of the absorbance related to Fer, clinker and carbonates, with the band at $959 \mathrm{~cm}^{-1}$ representing the hydrated silicate compounds becoming the principal one along with the emergence of a new band at $1073 \mathrm{~cm}^{-1}$ attributed to Si-O stretching in silicate. Relating this information to the XRD study, it can be suggested that the silica not only promoted the formation of CSHs (tobermorite and xonotlite) responsible for developing the early strength of cement, but also reacted with ionic species $\left(\mathrm{Na}^{+}, \mathrm{Mg}^{2+}\right.$, and $\left.\mathrm{Al}^{3+}\right)$ liberated from the hot alkali dissolution of Fer to form anorthite and diopside in the presence of calcium ions from the clinker. In agreement with the XRD results, the FTIR spectra did not show the additional formation of carbonated compounds in the silicamodified samples cured in water.

The spectra of the samples cured in the alkali carbonate environment at $270^{\circ} \mathrm{C}$ for $1 \mathrm{~d}$ were similar to those of the water-cured samples except for the incorporation of carbonaterelated bands. Again, the intensity of these bands in the unmodified samples was much higher than in the samples modified with silica.

Figure 5(b) shows the FTIR spectra of the damaged samples after $10 \mathrm{~d}$ of curing in water at $270^{\circ} \mathrm{C}$. In agreement with the XRD results, the spectra of the unmodified samples indicated the presence of both carbonated and non-carbonated silicate compounds with the principal and secondary bands at nearly $959 \mathrm{~cm}^{-1}$ and at $1073 \mathrm{~cm}^{-1}$, corresponding to $\mathrm{Si}-\mathrm{O}$ bond stretching, and several carbonate-related $\mathrm{C}-\mathrm{O}$ stretching bands at $1486,1451,853$ and $829 \mathrm{~cm}^{-1}$. Relating this evidence to the XRD reveals that the major crystalline non-carbonated silicates would be orthoenstatite, xonotlite (Mostafa et al., 2009), kilchoanite and andradite aluminian, while the carbonated silicates involve scawtite and spurrite. There were still Fer- and clinker-related bands present in the samples, clearly indicating that the hydration of the clinker and the dissolution of zeolite were not completed after $10 \mathrm{~d}$ of exposure.

The spectrum of the silica-modified cement after $10 \mathrm{~d}$ in water was similar to that of the $1 \mathrm{~d}$ autoclaved sample, highlighting accelerated dissolution of Fer and reactions with clinker in the presence of silica.

The surface spectrum of the damaged non-modified cement exposed for $10 \mathrm{~d}$ to the alkali carbonate environment (Figure 5(c)) showed a new reaction product identified as silica based on the newly developed bands at 1023 and $785 \mathrm{~cm}^{-1}$, respectively from $\mathrm{Si}-\mathrm{O}\left(V_{\text {as }} \mathrm{Si-O}\right)$ and $\left(\begin{array}{ll}V_{\mathrm{s}} & \mathrm{Si}-\mathrm{O}\end{array}\right)$ stretching vibrations (Ramasamy and Suresh, 2009; Saikia et al., 2008). The formation of silica as the major reaction by-product was due to the precipitation of silica in carbonate after dissolution of silicate compounds. This spectrum also showed the presence of some silicate and carbonate reaction products coexisting with the residue of clinker. As expected, the core of this sample had two major bands at 959 and $921 \mathrm{~cm}^{-1}$, attributed to silicate reaction products and clinker, but there were no quartz-related bands, indicating that, beneath the carbonated top surface layer, the cement remained intact. Thus, conceivably, the precipitation of silica may create a protective barrier layer abating the rate of further carbonation- induced erosion. For the silica-modified cement, the spectrum of the surface showed silica as a primary product in conjunction with the silicates (xonotlite and talc-1A) as secondary reaction products identified by XRD. The presence of residual clinker and carbonated compounds was negligible, supporting the XRD results. The underlying core area was composed of silicate- and sulfate-related reaction products.

Morphologies of silica-modified and unmodified samples cured in water or carbonate

The core morphologies of the damaged samples autoclaved for the total $10 \mathrm{~d}$ in water or carbonate were amorphous for the most part (see Figure 6 and Table 6) with some inclusions of needle-like crystals (points 1, 8, 9 and 12). The amorphous matrix was rich in silica for the silica-modified samples (points 6, 7 and 10) and rich in calcium for the watercured unmodified sample (point 13). The needle-shaped crystals had compositions typical of xonotlite and scawtite (points 1 and 8 ) and kilchoanite (point 12), supporting the XRD findings. Silica-rich mordenite composition was detected in some spots on the surfaces of the samples (2, 5 and 14). The surface compositions of both the silica-modified and unmodified cements were, for the most part, typical of silica and the morphologies showed depositions of amorphous and crystalline silica (points 3, 4, 11 and 15), in agreement with XRD and FTIR results. The carbon detected in the samples resulted from their carbonation and from the presence of carbon microfibres.

\section{Conclusions}

OPC type I/II clinker/Fer, Fer/silica and non-silica blends were tested for compressive strength recoveries and fracture closure under hydrothermal conditions at $270^{\circ} \mathrm{C}$ in alkali carbonate or water environments after imposed mechanical 

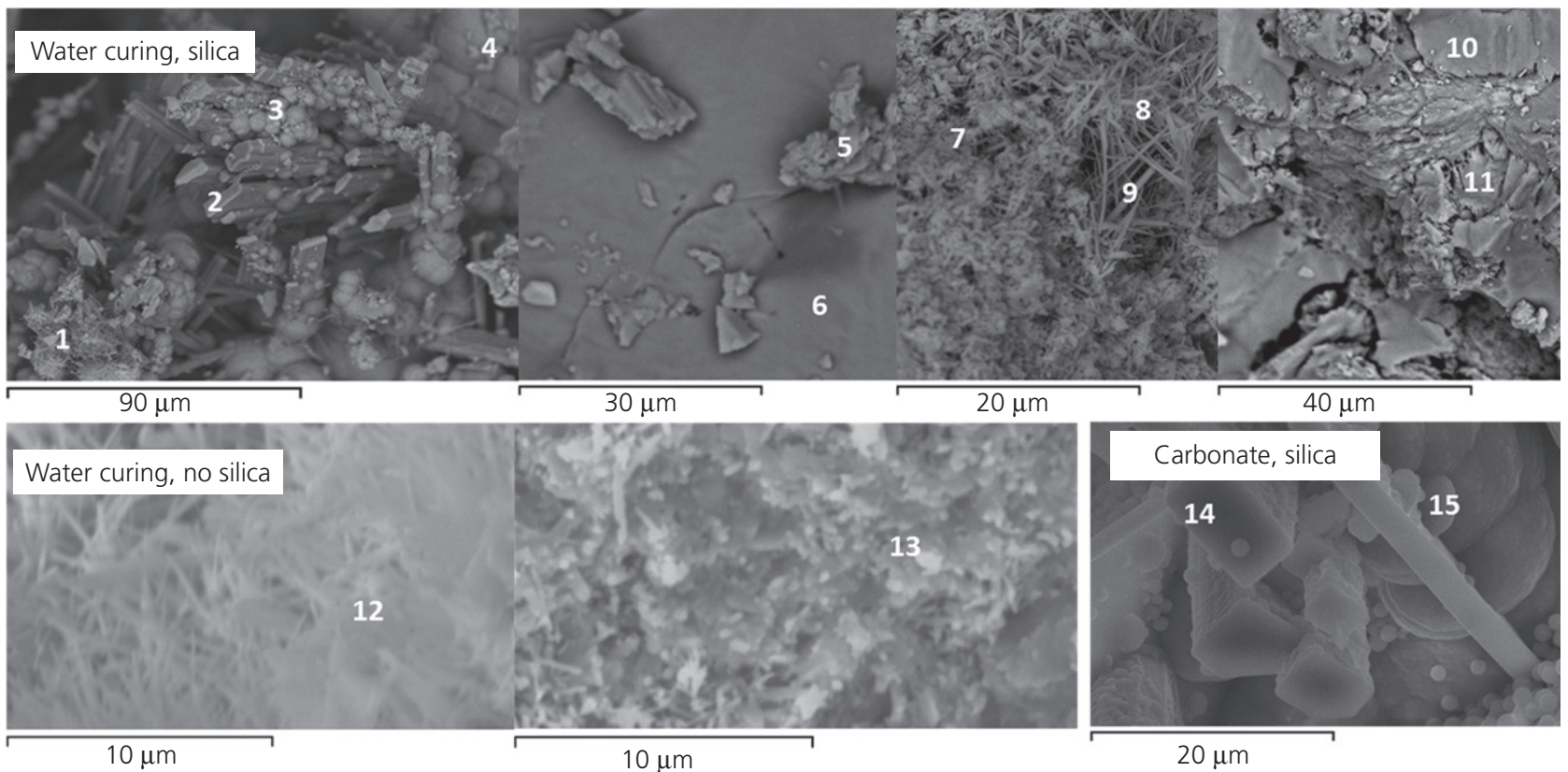

Figure 6. Scanning electron micrographs of typical cement microstructures of clinker/Fer samples cured for $10 \mathrm{~d}$ at $270^{\circ} \mathrm{C}$

Table 6. Elemental compositions of the points shown in Figure 6

\begin{tabular}{|c|c|c|c|c|c|c|c|c|}
\hline Point & Carbon & Sodium & Magnesium & Aluminium & Silicon & Calcium & Iron & Possible phase \\
\hline 1 & $5 \cdot 4$ & $0 \cdot 39$ & 0.42 & $4 \cdot 6$ & 14 & 14 & $0 \cdot 81$ & Xonotlite, non-reacted Fer \\
\hline 2 & - & 1.6 & - & 1.6 & 31 & - & - & Mordenite, silica \\
\hline 3 & - & 0.72 & - & 0.39 & 33 & - & - & Silica \\
\hline 4 & - & 0.56 & - & 0.32 & 33 & - & - & Silica \\
\hline 5 & - & 3.9 & - & $3 \cdot 2$ & 28 & - & - & Mordenite \\
\hline 6 & - & 0.23 & - & 0.3 & 33 & - & - & Amorphous matrix \\
\hline 7 & 8.8 & 0.43 & - & 1.0 & 14 & 13 & 0.23 & Amorphous matrix \\
\hline 8 & 11 & - & - & $1 \cdot 1$ & 13 & 13 & 0.31 & Xonotlite, scawtite \\
\hline 9 & $8 \cdot 3$ & $0 \cdot 31$ & 0.64 & $1 \cdot 2$ & 15 & 13 & $0 \cdot 3$ & Fer, xonotlite, \\
\hline 10 & 19 & - & - & 0.73 & 14 & - & - & Amorphous silica-rich matrix \\
\hline 11 & $5 \cdot 2$ & - & - & - & 28 & - & - & Silica \\
\hline 12 & 12 & - & $0 \cdot 19$ & 0.63 & 10 & 14 & 0.24 & Kilchoanite \\
\hline 13 & $2 \cdot 9$ & - & $0 \cdot 13$ & 0.52 & 14 & 23 & 0.26 & Amorphous matrix \\
\hline 14 & - & 1.8 & - & $1 \cdot 8$ & 31 & - & - & Mordenite, silica \\
\hline 15 & 9.9 & 0.47 & - & 0.22 & 23 & - & - & Silica \\
\hline
\end{tabular}

damage. The following general conclusions can be drawn from the study.

(a) Compressive strength recoveries were outstanding (above $100 \%$ ) for repeatedly damaged silica-modified samples healed in carbonate and for unmodified samples healed in water at $270^{\circ} \mathrm{C}$ for $10 \mathrm{~d}$. The strength recoveries of the unmodified samples in carbonate were comparable to those of the OPC/silica blends and those of the silica-modified samples were more than $100 \%$ after the first imposed damage and less than $60 \%$ after the second damage. The decrease in recovery was due to the increased sample brittleness after the first healing period, resulting in the formation of long, wide cracks in the second damage that were difficult to repair.

(b) The $0.25 \mathrm{~mm}$ cracks were closed after $10 \mathrm{~d}$ in carbonate for the silica-modified samples and partially closed for the unmodified ones. On the other hand, crack sealing was insignificant for the samples healed in water.

(c) The recoveries of compressive strength were the result of continuous clinker hydration and fast high-temperature alkali decomposition and interactions of Fer. The crystalline structure of Fer was lost after the first $24 \mathrm{~h}$ of $270^{\circ} \mathrm{C}$ exposure for samples cured in carbonate or water. The decomposed zeolite released silicon, magnesium, aluminium and iron, which participated in the creation of new phases, contributing to the strength recoveries and 
sealing of the fractures. The formation of mixed calcium aluminium silicates and calcium magnesium silicates suggests that decomposition and reactions of the zeolite and hydration of the clinker phases were concurrent.

(d) The new crystalline phases responsible for strength recoveries included various magnesium silicates, calcium silicates, calcium aluminium silicates and calcium aluminium iron silicates. The crystalline products sealing the cracks were mostly silica, talc and high-temperaturestable zeolites (mordenite, analcime and thomsonite).

(e) The decomposition of Fer was faster for samples cured in the alkali carbonate environment than for samples cured in water. This, along with the partial calcium removal as soluble calcium bicarbonate and the lower solubility of silicon, led to increased precipitation of crystalline and amorphous silica, resulting in more efficient sealing of the cracks in the carbonate-cured samples. The formation of talc through the transformation of calcium magnesium silicates (diopside and akermanite) to various magnesium silicates (protoenstatite and ilmenite) as a result of calcium removal by carbonation and through dolomite skarnification also contributed to the process of fracture filling.

( $f$ ) The major crystalline hydration products of the clinker were xonotlite in the silica-modified samples and kilchoanite along with carbonated calcium silicates (scawtite and spurrite), which became the principal crystalline products in the carbonate environment, for the unmodified samples. Carbonated CSHs were persistent after $10 \mathrm{~d}$ of curing and likely responsible for the good initial strength build-up and first-time recoveries but increased the samples' brittleness and, consequently, decreased second-time recoveries.

( $g$ ) The study showed that natural zeolites unstable under high-temperature alkaline conditions may serve as a latent source of aluminium, silica and other cations for new phases and the strength recovery of damaged cements under high-temperature geothermal conditions.

\section{Acknowledgements}

This paper was based on work supported by the Geothermal Technologies Office of the US Department of Energy (DoE) Office of Energy Efficiency and Renewable Energy (EERE), under the auspices of the US DoE, Washington, DC, under contract DE-AC02-98CH 10886. Research was carried out in part at the Center for Functional Nanomaterials, Brookhaven National Laboratory, which is supported by the US DoE Office of Basic Energy Sciences, under contract DE-SC0012704.

\section{REFERENCES}

Ahmadi B and Shekarchi M (2010) Use of natural zeolite as a supplementary cementitious material. Cement \& Concrete Composites 32(2): 134-141.
Alexander KM (1960) Reactivity of ultrafine powders produced from siliceous rocks. Journal of the American Concrete Institute 57(11): 557-569.

Al-Hosney HA and Grassian VH (2005) Water, sulfate dioxide and nitric acid adsorption on calcium carbonate: a transmission and ATR-FTIR study. Physical Chemistry Chemical Physics 7(6): 1266-1276.

Almecida RM and Pantano CG (1990) Structural investigation of silica gel films by infrared spectroscopy. Journal of Applied Physics 68(8): 4225-4232.

Amin MN, Kim JS, Lee Y and Kim JK (2009) Simulation of the thermal stress in mass concrete using a thermal stress measuring device. Cement and Concrete Research 39(3): 154-164.

Armbruster T and Gunter ME (1991) Stepwise dehydration of heulandite-clinoptilolite from Succor creek, Oregon, U.S.A.: a single-crystal x-ray study at $100 \mathrm{~K}$. American Mineralogist 76(11-12): 1872-1883.

Ates A and Hardacre C (2012) The effect of various treatment conditions on natural zeolite: ion exchange, acidic, thermal and steam treatments. Journal of Colloid and Interface Science 372(1): $130-140$.

Bensted J (1988) Special cements. In Lea's Chemistry of Cement and Concrete (Hewlett P (ed.)). Elsevier, Oxford, UK, pp. 783-840.

Bilim C (2011) Properties of cement mortars containing clinoptilolite as supplementary cementitious material. Construction and Building Materials 25(8): 3175-3180.

Bonilla A, Baudouin D and Perez-Ramirez J (2009) Desilication of ferrierite zeolite for porosity generation and improved effectiveness in polyethylene pyrolysis. Journal of Catalysis 265(2): $170-180$.

Cakicioglu-Ozkan F and Ulku S (2005) The effect of $\mathrm{HCl}$ treatment on water vapor adsorption characteristics of clinoptilolite rich natural zeolite. Microporous and Mesoporous Materials 77(1): 47-53.

Christidis GE, Moraetis D, Keheyan E et al. (2003) Chemical and thermal modification of natural HEU-type zeolite materials from Armenia, Georgia and Greece. Applied Clay Science 24(1): 79-91.

Collepardi M, Marcialis A, Massidda L and Sanna U (1976) Low pressure steam curing of compacted lime-pozzolan mixture. Cement and Concrete Research 6: 497-506, https://doi.org/10.1016/0008-8846 (76)90078-8.

Costa U and Massazza F (1977) Influence of thermal treatment on the activity of some natural pozzolans with lime. Cemento $\mathbf{7 4}$ : $105-122$.

Curkovic L, Cerjan-Stefanovic S and Filipan T (1997) Metal ion exchange by natural and modified zeolites. Water Research 31(6): 1379-1382.

Day RL and Shi C (1994) Influence of the fineness of pozzolan on the strength of lime natural-pozzolan cement pastes. Cement and Concrete Research 24(8): 1485-1491.

Dubkov KA, Ovanesyan NS, Shteinman AA, Starokon EV and Panov GI (2002) Evolution of iron states and formation of $\alpha$-sites upon activation of FeZSM-5 zeolites. Journal of Catalysis 207(2): 341-352.

Edvardsen C (1999) Water permeability and autogenous healing of cracks in concrete. ACI Materials Journal 96(4): 448-454.

Elaiopoulos K, Perraki T and Grigoropoulou E (2010) Monitoring the effect of hydrothermal treatments on the structure of a natural zeolite through a combined XRD, FTIR, XRF, SEM and N2-porosimetry analysis. Microporous and Mesoporous Materials 134(1-3): 29-43.

Ewell RH, Bunting EN and Geller RF (1935) Thermal decomposition of talc: research paper RP848. Journal of Research of the National Bureau of Standards 15: 551-556. 
Fernandez-Carrasco L, Torrens-Martin D, Morales LM and MarinezRemirez S (2012) Infrared spectroscopy in the analysis of building and construction materials. In Infrared Spectroscopy - Material Science, Engineering and Technology (Theophile T (ed.)). In Tech, Rijeka, Croatia. See http://www.intechopen.com/books/ infrared-spectroscopy-materials-science-engineering-andtechnology/infrared-spectroscopy-of-cementitious-materials (accessed 13/07/2017).

Foldvari M (2011) Handbook of Thermogravimetric System of Minerals and its Use in Geological Practice. Geological Institute of Hungary, Budapest, Hungary.

Frost RL, Weier ML and Martens W (2005) Thermal decomposition of jarosites of potassium, sodium and lead. Journal of Thermal Analysis and Calorimetry 82(1): 115-118.

Gaki A, Chrysafi R and Kakali G (2007) Chemical synthesis of hydraulic calcium aluminate compounds using the Pechini technique. Journal of the European Ceramic Society 27(2): 1781-1784.

García-Lodeiro I, Palomo A, Fernández-Jimenez A and Macphee DE (2011) Compatibility studies between $\mathrm{N}-\mathrm{A}-\mathrm{S}-\mathrm{H}$ and $\mathrm{C}-\mathrm{A}-\mathrm{S}-\mathrm{H}$ gels. Study in the ternary diagram $\mathrm{Na}_{2} \mathrm{O}-\mathrm{CaO}-\mathrm{Al}_{2} \mathrm{O}_{3}-\mathrm{SiO}_{2}-\mathrm{H}_{2} \mathrm{O}$ Cement and Concrete Research 41(9): 923-931.

Gunasekaran S, Anbalagan G and Pandi S (2006) Raman and infrared spectra of carbonate of calcite structure. Journal of Raman Spectroscopy 37(9): 892-899.

Habert G, Choupay N, Montel JM, Guillaume D and Escadeillas G (2008) Effect of the secondary minerals of the natural pozzolans on their pozzolanic activity. Cement and Concrete Research 38(7): 963-975.

Hemings RT, Berry EE, Cornelius BJ and Golden DM (1989) Evaluation of acid-leached fly ash as pozzolan. Materials Research Society Proceeding 136: 141-161, https://doi.org/10.1557/PROC-136-141.

Huang H, Ye G and Damidot D (2013) Characterization and quantification of self-healing behaviors of microcracks due to further hydration in cement paste. Cement and Concrete Research 52: 71-81, https://doi.org/10.1016/j.cemconres.2013.05.003.

Huang H, Ye G and Damidot D (2014) Effect of blast furnace slag on self-healing of microcracks in cementitious materials. Cement and Concrete Research 60: 68-82, https://doi.org/10.1016/j.cemconres. 2014.03.010.

Ishida H, Yamazaki S, Sasaki K, Okada Y and Mitsuda T (1993) $\alpha$-Dicalcium silicate hydrate: preparation, decomposition and its hydration. Journal of the American Ceramic Society 76(7): 1707-1712.

Joshi MS, Joshi VV, Choudhari AL and Kasture MW (1997) Structure studies of natural heulandite using infrared spectroscopy. Material Chemistry and Physics 48(2): 160-163.

Kalousek GL and Nelson EB (1978) Hydrothermal reactions of dicalcium silicate and silica. Cement and Concrete Research 8(3): 283-289.

Karadurt C and Topcu LB (2011) Effect of blended cements produced with natural zeolite and industrial by-products on alkali-silica reaction and sulfate resistance of concrete. Construction and Building Materials 25: 1789-1795, https://doi.org/10.1016/ j.conbuildmat.2010.11.087.

Kiwi-Minsker L, Bulushev DA and Renken A (2003) Active sites in HZSM-5 with low Fe content for the formation of surface oxygen by decomposing $\mathrm{N}_{2} \mathrm{O}$ : is every deposited oxygen active? Journal of Catalysis 219: 273-285, https://doi.org/10.1016/S00219517(03)00222-7.

Liguori B, Caputo D and lucolano F (2015) Fiber-reinforced lime-based mortars: Effect of zeolite addition. Construction and Building Materials 77: 455-460, https://doi.org/10.1016/j.conbuildmat.2014. 12.067.

McConnell JDC (1955) A chemical, optical and x-ray study of scawtite from Ballycraigy, Larne, N. Ireland. American Mineralogist 40(5-6): 510-514.
McCulloch J, Gastineau J, Bour DL and Ravi K (2003) Life-cycle modeling of wellbore cement systems used for enhanced geothermal system development. Transactions of the Geothermal Resources Council 27: $12-15$.

Mertens G, Snellings K, Van Balen K et al. (2009) Pozzolanic reactions of common natural zeolites with lime and parameters affecting their reactivity. Cement and Concrete Research 39(3): 233-240.

Milodowski AE, Rochelle CA, Lacinska A and Wagner D (2011) A natural analogue study of $\mathrm{CO}_{2}$-cement interaction: Carbonation of calcium silicate hydrate-bearing rocks from Northern Ireland. Energy Procedia 4: 5235-5242, https://doi.org/10.1016/j.egypro. 2011.02.502.

Misaelides P, Godelitsas A, Link F and Bauman H (1996) Application of the ${ }^{27} \mathrm{Al}(\rho, \gamma)^{28} \mathrm{Si}$ nuclear reaction to the characterization of the near-surface layers of acid-treated HEU-type zeolite crystals. Microporous Materials 6(1): 37-42.

Mitsuda T, Asami J, Matsubara Y and Toraya H (1985) Hydrothermal formation of gamma-dicalcium silicate from lime-silica mixtures using a rapid-heating method and its reaction to give kilchoanite or calciochondrodite. Cement and Concrete Research 15(4): 613-621.

Mitsuda T and Banno S (1977) Hydrothermal formation of pseudowollastonite from lime-quartz mixtures at $165^{\circ} \mathrm{C}$ and $200^{\circ} \mathrm{C}$. Cement and Concrete Research 7(4): 457-460.

Mollah MYA, Yu W, Schennach R and Cocke DL (2000) A Fourier transform infrared spectroscopic investigation of the early hydration of Portland cement and the influence of sodium lignosulfonate. Cement and Concrete Research 30(2): 267-273.

Mostafa NY, Shaltout AA, Omar H and Abo-El-Enein SA (2009) Hydrothermal synthesis and characterization of aluminium and sulfate substituted $1.1 \mathrm{~nm}$ tobermorites. Journal of Alloys and Compounds 467(1): 332-337.

Mozgawa W (2001) The relation between structure and vibrational spectra of natural zeolite. Journal of Molecular Structure 596(1-3): 129-137.

Ortega EA, Cheeseman C, Knight J and Loizidou M (2000) Properties of alkali-activated clinoptilolite. Cement and Concrete Research 30(10): 1641-1646.

Otero Areán C, Rodríguez Delgado M, Frolich K et al. (2008) Computational and Fourier transform infrared spectroscopic studies on carbon monoxide adsorption on the zeolites Na-ZSM-5 and K-ZSM-5: evidence of dual-cation sites. Journal of Physical Chemistry C 112(12): 4658-4666.

Özen S, Göncüoglu MC, Liguori B et al. (2016) A comprehensive evaluation of sedimentary zeolites from Turkey as pozzolanic addition of cement- and lime-based binders. Construction and Building Materials 105: 46-61, https://doi.org/10.1016/ j.conbuildmat.2015.12.055.

Perez-Ramirez J, Kapteijn F, Groen JC et al. (2003) Steam-activated FeMFI zeolites. Evolution of iron species and activity in direct $\mathrm{N}_{2} \mathrm{O}$ decomposition. Journal of Catalysis 214(1): 33-45.

Perraki T, Kakali G and Kontori E (2005) Characterization and pozzolanic activity of thermally treated zeolite. Journal of Thermal Analysis and Calorimetry 82(1): 109-113.

Perraki T, Kontori E, Tsivilis S and Kakali G (2010) The effect of zeolite on the properties and hydration of blended cements. Cement and Concrete Research 32(2): 128-133.

Qian SZ, Zhou J and Schlangen E (2010) Influence of curing conditions and precracking time on the self-healing behavior of engineered cementitious composites. Cement \& Concrete Composites 32(9): 686-693.

Ramasamy V and Suresh G (2009) Mineral characterization and crystalline nature of quartz in Ponnaiyar river sediments, Tamilnadu, India. American-Eurasian Journal of Science Research 4(2): 103-107. 
Ravi K, Bosma M and Gastebled O (2002) Improve the economics of oil and gas wells by reducing the risk of cement failure. Proceedings of IADC/SPE 74497, Drilling Conference, Dallas, $T X, U S A$.

Sahmaran M, Keskin SB, Ozerkan G and Yaman IO (2008) Self-healing of mechanically-loaded self-consolidating concrete with high volumes of fly ash. Cement \& Concrete Composites 30(10): 872-879.

Sahmaran M, Yildirim G and Erdem TK (2013) Self-healing capability of cementitious composites incorporating different supplementary cementitious materials. Cement \& Concrete Composites 35(1): 89-101.

Saikia BJ, Parthasarathy G and Sarmah NC (2008) Fourier transform infrared spectroscopic estimation of crystallinity in $\mathrm{SiO}_{2}$ based rocks. Bulletin of Materials Science 31(5): 775-779.

Seraj S, Ferron RD and Juenger MCG (2016) Calcining natural zeolites to improve their effect on cementitious mixture workability. Cement and Concrete Research 85: 102-110, https://doi.org/ 10.1016/j.cemconres.2016.04.002.

Shi C and Day RL (1993) Chemical activation of blended cement made with lime and natural pozzolans. Cement and Concrete Research 23(6): 1389-1396.

Stevula L and Petrovic J (1981) Formation of scawtite from mixtures of $\mathrm{CaO}$, magnesite and quartz under hydrothermal conditions. Cement and Concrete Research 11(4): 549-557.

Taddei P, Modena E, Tinti A et al. (2014) Effect of the fluoride content on the bioactivity of calcium silicate-based endodontic cements. Ceramics International 40(3): 4095-4107.

Talaiekhozan A, Keyvanfar A, Shafaghat A et al. (2014) A review of self-healing concrete research development. Journal of Environmental Treatment Techniques 2(1): 1-11.

Teodoriu C, Kosinowski C, Amani MN, Schubert J and Shadravan A (2013) Wellbore integrity and cement failure at HPHT conditions. International Journal of Engineering and Applied Science 2(2): $1-13$.

Termkhajornkit P, Nawa T and Yamashiro Y (2009) Self-healing ability of fly ash-cement systems. Cement \& Concrete Composites 31(3) 195-203.

Thompson MH and Palmer RA (1988) In situ Fourier transform infrared diffuse reflectance and photoacoustic spectroscopy characterization of sulfur-oxygen species resulting from the reaction of $\mathrm{SO}_{2}$ with $\mathrm{CaCO}_{3}$. Applied Spectroscopy 42(6): 945-951.
Uzal B and Turanli L (2012) Blended cements containing high volume of natural zeolites: properties, hydration and paste microstructure. Cement \& Concrete Composites 34(1): 101-109.

Uzal B, Turanlı L, Yücel H, Göncüoglu MC and Çulfa A (2010) Pozzolanic activity of clinoptilolite: a comparative study with silica fume, fly ash and a non-zeolitic natural pozzolan. Cement and Concrete Research 40(3): 398-404.

Vejmelkova E, Konakova D, Kulovana T et al. (2015) Engineering properties of concrete containing natural zeolite as supplementary cementitious material: strength, toughness, durability, and hygrothermal performance. Cement \& Concrete Composites 55: 259-267, https://doi.org/10.1016/j.cemconcomp.2014.09.013.

Virta RL (2015) Zeolites (Natural). US Geological Survey, Reston, VA, USA. See http://minerals.usgs.gov/minerals/pubs/ commodity/zeolites/mcs-2015-zeoli.pdf (accessed 13/07/2017).

Wloch E, Lukaszczyk A, Zurek Z and Sulikowski B (2006) Synthesis of ferrierite coatings on the $\mathrm{FeCrAl}$ substrate. Catalyst Today 114(2-3): 231-236.

Xyla AG and Koutsoukos PG (1989) Quantitative analysis of calcium carbonate polymorphs by infrared spectroscopy. Journal of the Chemical Society, Faraday Transactions 1(85) 3165-3172.

Yilmaz B, Ucar A, Oteyaka B and Uz V (2007) Properties of zeolite tuff (clinoptilolite) blended Portland cement. Building and Environment 42(11): 3808-3815.

YImen R and Jaglid U (2013) Carbonation of Portland cement studied by diffuse reflection Fourier transform infrared spectroscopy. International Journal of Concrete Structures and Materials 7(1): 119-125.

Ylmen R, Jaglid U, Steenari BM and Panas I (2009) Early hydration and setting of Portland cement monitored by IR, SEM and Vicat techniques. Cement and Concrete Research 39(5): $433-439$.

Zhang W, Han X, Liu X et al. (2002) Investigation of the microporous structure and non-framework aluminum distribution in dealuminated nanosized HZSM-5 zeolite by ${ }^{129}$ Xe NMR spectroscopy. Microporous and Mesoporous Materials 53: 145-152.

Zhijun T, Yanjun Z and Jianghong J (2013) Technology for improving life of thermal recovery well casing. Advances in Petroleum Exploration and Development 5(1): 71-76. 